UCRL-JC-132384

Preprint

\title{
The Lean Oxidation of Iso-Octane at Elevated Pressures
}

\author{
J.-S. Chen
}

T. A. Litzinger

H. J. Curran

This paper was prepared for submittal to Western States Section Combustion Institute

Seattle, WA

October 26-27, 1998

October 30, 1998

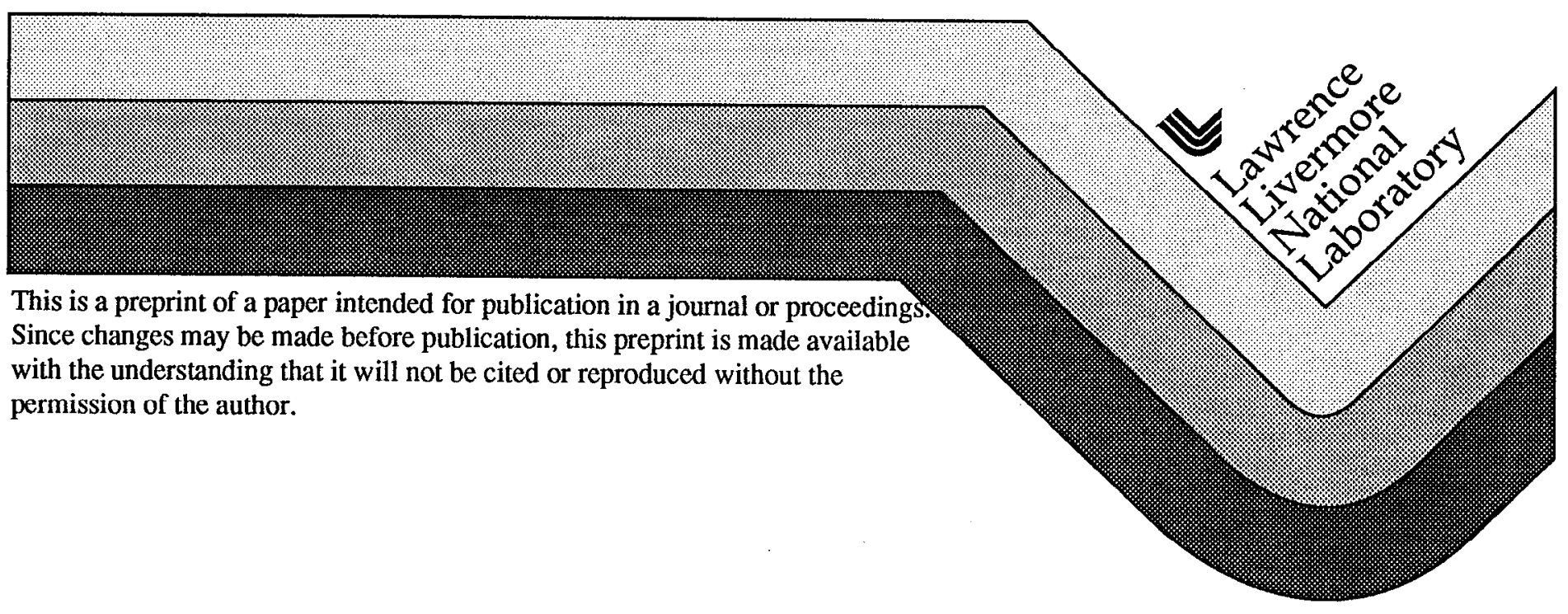




\section{DISCLAIMER}

This document was prepared as an account of work sponsored by an agency of the United States Government. Neither the United States Govemment nor the University of Califormia nor any of their employees, makes any warranty, express or implied, or assumes any legal liability or responsibility for the accuracy, completeness, or usefulness of any information, apparatus, product, or process disclosed, or represents that its use would not infringe privately owned nghts. Reference herein to any specific commercial product, process, or service by trade name, trademark, manufacturer, or otherwise, does not necessarily constitute or imply its endorsement, recommendation, or favoring by the United States Government or the University of California. The views and opinions of authors expressed herein do not necessarily state or reflect those of the United States Government or the University of Califomia, and shall not be used for advertising or product endorsement purposes. 


\title{
The Lean Oxidation of Iso-octane at Elevated Pressures
}

\author{
J.-S. Chen and T. A. Litzinger \\ Department of Mechanical Engineering, Pennsylvania State University, University Park, \\ PA 16802. \\ H. J. Curran \\ Lawrence Livermore National Laboratory, Livermore, CA 94551.
}

\begin{abstract}
Both spark-ignition and compression-ignition engines burn large molecular-weight blended fuels, a class to which the primary reference fuels (PRF), n-heptane and iso-octane belong. In this study experiments were performed using iso-octane in a high pressure flow reactor at a temperature of $925 \mathrm{~K}$, at 3,6 and 9 atm pressure and with a fuel/air equivalence ratio of approximately 0.05 . Many hydrocarbon and oxygenated hydrocarbon intermediates were identified and quantified as a function of time. These experimental results provide a stringent test of the low temperature chemistry portion of a kinetic model as they emphasise the importance of alkyl radical addition to molecular oxygen and internal $\mathrm{H}$-atom isomerization reactions relative to alkyl radical decomposition reactions. A detailed chemical kinetic mechanism is used to simulate these experiments. We provide comparisons of model predictions with experimentally measured species profiles and describe how each species is formed as predicted by the detailed model.
\end{abstract}




\section{Introduction}

Iso-octane is a primary reference fuel (octane number $=100$ ) and is used together with $\mathrm{n}$ heptane (octane number $=0$ ) to determine the octane number of a gasoline fuel. Iso-octane is a branched paraffin hydrocarbon, which represents one of the major chemical classes in gasoline fuels. The molecular weight of iso-octane is about the average molecular weight of current gasoline fuels. All of these characteristics make the study of iso-octane oxidation significant for researchers who seek to improve the efficiency of the spark-ignited engines, to reformulate gasoline fuels, and to build a detailed chemical mechanism for hydrocarbons.

The oxidation of iso-octane is affected by several parameters, i.e. pressure, temperature, and initial concentrations of reactants. Many studies of iso-octane have been performed at stoichiometric conditions while pressure and temperature were varied. However, because of the possibility of explosion, the fuel and oxygen were diluted with large quantities of nitrogen to ensure the safe operation of the experimental reactors. Previously, Dryer and Brezinsky [1] performed experiments using iso-octane at stoichiometric but highly dilute conditions, in which the mole fraction of iso-octane, oxygen, and nitrogen were $0.14 \%, 1.78 \%$, and $98.08 \%$ respectively. Although the concentrations of all three species have been altered significantly, the diluted stoichiometric condition is still a valuable technique in studying and understanding the oxidation mechanism of hydrocarbons. Lean oxidation experiments are unique in analysing the kinetic processes responsible for the oxidation of iso-octane. In lean oxidation experiments, by contrast to dilute stoichiometric conditions, the concentration of oxygen and nitrogen are almost the same as those in an actual stoichiometric oxidation with only the concentration of iso-octane reduced significantly. For example, at an equivalence ratio of 0.05 , the mole fraction of iso-octane, oxygen, and nitrogen are $0.08 \%, 20.99 \%$, and $78.92 \%$, respectively. It is the objective of this study to investigate the oxidation of isooctane at lean conditions, with an equivalence ratio of 0.05 , as pressure increases from 3 to $9 \mathrm{~atm}$ while the average temperature is fixed at $926 \mathrm{~K}$.

\section{Experimental}

The oxidation of iso-octane was performed in a plug-flow reactor at elevated pressures. The details of the experimental setup can be found in the thesis of Hunter [2]. The pressure was set at 3,6, and 9 atm. The operating temperature inside the flow reactor was controlled at about $926 \mathrm{~K}$. Iso-octane was vaporized by injecting heated iso-octane liquid into a hot nitrogen crossflow in a fuel vaporizer. The mixture of iso-octane vapor and nitrogen was then injected into the mixer inside the flow reactor to mix with the heated compressed air crossflow. The mixture of reactants flowed through a diffuser and then entered the test section. The equivalence ratio was approximately 0.05 . The temperatures were measured and samples taken at pre-determined locations inside the test section. Based on the flow rate, an equivalent residence time could be determined from the point of fuel injection to each sample point. In this way, the temporal evolution of species can be studied. The collected samples were analyzed by an HP $5880 \mathrm{~A}$ GC equipped with an HP-1 column $(60 \mathrm{~m} \times 0.53 \mathrm{~mm}$ $\mathrm{x} 5.5 \mathrm{~m}$ ) and a FID detector at $523 \mathrm{~K}$. The oven temperature was started at $233 \mathrm{~K}$ to separate methane and lighter species and increased to a maximum temperature of $418 \mathrm{~K}$. The species were then identified by comparing the calculated retention index with references [3, 4]. A GC/MS was utilized to facilitate the verification of some species. 


\section{Chemical Kinetic Model}

Modeling computations were performed using the HCT modeling code [5]. This code permits the use of a variety of boundary and initial conditions for reactive systems. The flow reactor is simulated as an isobaric plug flow with negligible axial diffusion of species and energy. The detailed chemical kinetic reaction mechanism used in these calculations is based on our previous studies [6]-[11], and on the hierarchical nature of reacting systems starting with a core mechanism describing $\mathrm{H}_{2} / \mathrm{O}_{2}$ and $\mathrm{CO}$ oxidation. To this is added the progressively larger $\mathrm{C}_{1}-\mathrm{C}_{8}$ mechanism with the complete model consisting of approximately 850 different chemical species and 3570 elementary reactions.

In our more recent modeling work we have described the way in which we estimate rate constant expressions associated with the low temperature oxidation mechanism for $n$ heptane [11]. By analogy, these rate constants have been applied to the iso-octane mechanism and relevant sub-mechanisms, although we have used experimentally determined rate constants wherever possible. In addition, the thermodynamic properties of the relevant stable parent and radical species were obtained by group additivity using THERM [12] with updated $\mathrm{H} / \mathrm{C} / \mathrm{O}$ groups and bond dissociation groups [13]. The thermochemical data allow calculation of reverse reaction rate constants by microscopic reversibility. A full listing of the reaction mechanism can be obtained by Internet electronic mail (curran6@llnl.gov) or on disk by writing to the authors.

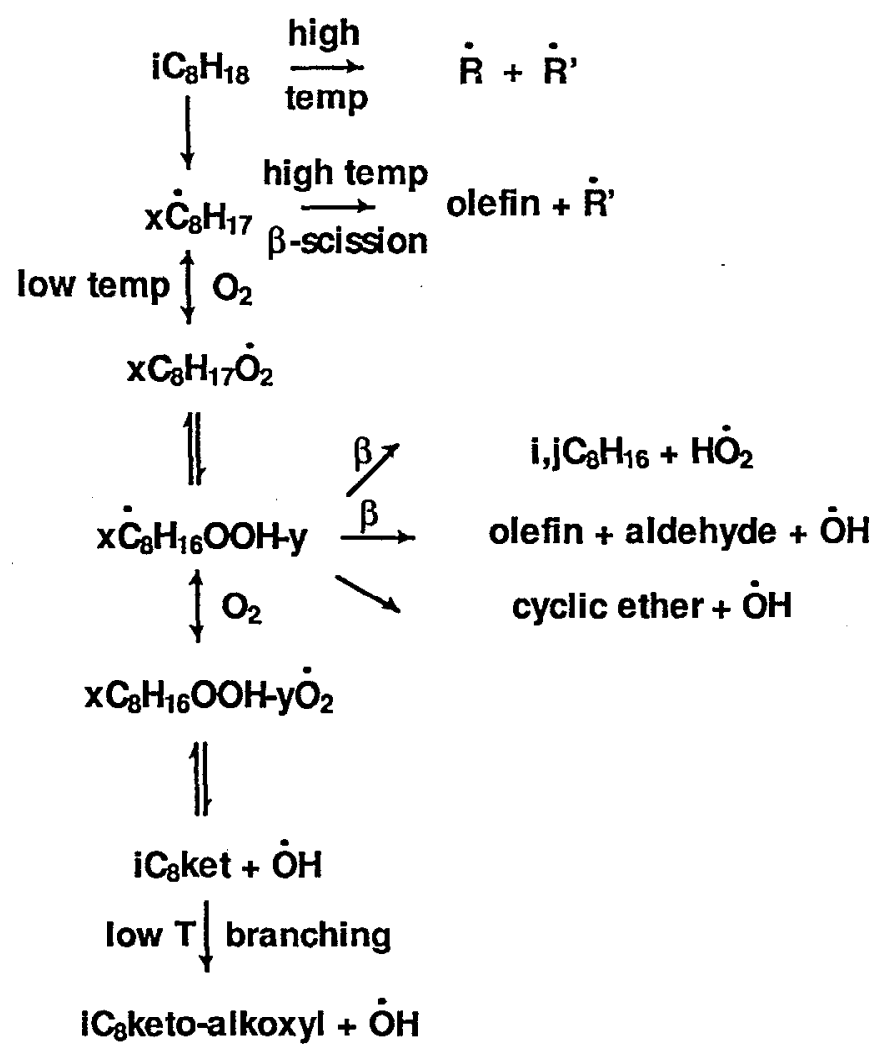

Figure 1: Simplified kinetic scheme for iso-octane oxidation. 


\section{Iso-octane Oxidation: Results and Discussion}

The overall reaction scheme included in this study for iso-octane oxidation is depicted in Fig. 1. The naming conventions used are $\dot{\mathrm{R}}$ and $\dot{\mathrm{R}}^{\prime}$, denoting alkyl radicals; in $\mathrm{x}_{8} \dot{\mathrm{H}}_{16} \mathrm{OOH}-$ $y, x$ denotes the site of the hydroperoxyl group and $y$ the radical site for two of the four distinct sites on the iso-octane molecule shown in $\mathrm{Fig} .2$, and $\mathrm{iC}_{8}$ ket refers to iso-octyl ketohydroperoxide species.

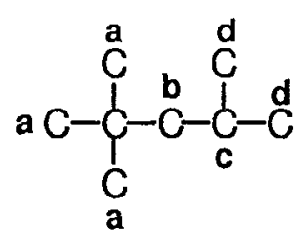

Figure 2: Iso-octane with its four distinct sites for H-atom abstraction.

Iso-octane has four distinct sites for $\mathrm{H}$-atom abstraction, Fig. 2. Each of the iso-octyl radicals formed will lead to a different set of products. For example, abstraction from site ' $a$ ' followed by $\beta$-scission will lead to isobutene and an iso-butyl radical, while abstraction of a secondary $\mathrm{H}$-atom (site ' $\mathrm{b}$ ') will produce a methyl radical and both 2,4-dimethyl-pent-2-ene and 4,4-dimethyl-pent-2-ene.

Initiation of fuel oxidation occurs via the following two reactions:

$$
\begin{aligned}
\mathrm{iC}_{8} \mathrm{H}_{18}+\mathrm{O}_{2} & \longrightarrow \dot{\mathrm{C}}_{8} \mathrm{H}_{17}+\mathrm{HO}_{2} \\
\mathrm{iC}_{8} \mathrm{H}_{18} & \longrightarrow \text { decomposition products. }
\end{aligned}
$$

At low and intermediate temperatures, the overall reaction pathway proceeds via $\mathrm{H}$-atom abstraction from the fuel primarily by $\dot{\mathrm{O}} \mathrm{H}$ and $\mathrm{HO}_{2}$ atoms and to a lesser extent by $\dot{\mathrm{CH}}_{3}$, $\dot{\mathrm{H}}, \dot{\mathrm{O}}, \mathrm{CH}_{3} \dot{\mathrm{O}}_{2}$ and $\mathrm{O}_{2}$. At high temperatures iso-octane decomposition, in addition to $\mathrm{H}-$ atom abstraction, also contributes to initiation of fuel oxidation producing relatively small alkyl radical species. At low temperatures iso-octyl radicals undergo addition to molecular oxygen to produce iso-octylperoxyl radicals, $\mathrm{xC}_{8} \mathrm{H}_{17} \dot{\mathrm{O}}_{2}$, followed by an internal $\mathrm{H}$-atom isomerization, a second addition to molecular oxygen and a subsequent isomerization and then a decomposition of a stable ketohydroperoxide species which results in chain branching. At intermediate temperatures the iso-octyl radical can also undergo $\beta$-scission creating a smaller olefin and alkyl radical species. Chain branching at intermediate temperatures occurs primarily through the sequence, fuel $+\mathrm{HO}_{2}=\dot{\mathrm{R}}+\mathrm{H}_{2} \mathrm{O}_{2}$ and $\mathrm{H}_{2} \mathrm{O}_{2}+\mathrm{M}=\dot{\mathrm{O}} \mathrm{H}+\dot{\mathrm{O}} \mathrm{H}+\mathrm{M}$, and at high temperatures through the reaction $\dot{\mathrm{H}}+\mathrm{O}_{2}=\dot{\mathrm{O}}+\dot{\mathrm{O}} \mathrm{H}$. Under the conditions of this study both low and high temperature chemistry contribute to fuel oxidation.

There are 25 measured intermediate hydrocarbon species identified from samples collected at $9 \mathrm{~atm}$. The species can be divided into four groups; cyclic ethers, olefins and acetylene, carbonyls, and paraffins. Cyclic ether species include 2,2,4,4-tetramethyl-tetrahydro-furan, 2isopropyl-3,3-dimethyl-oxetane, 2-tert-butyl-3-methyl-oxetane, and iso-butene oxide. Olefins include 2,4,4-trimethyl-1-pentene, 2,4,4-trimethyl-2-pentene, 4,4-dimethyl-1-pentene, trans4,4-dimethyl-2-pentene, 2,4-dimethyl-1-pentene, 2,4-dimethyl-2-pentene, 2-methyl-1-butene, 
2-methyl-1,3-butadiene, iso-butene, propene, propadiene, and ethene. Carbonyl species include 2,2-dimethyl-propanal, iso-butyraldehyde, methacrolein, propionaldehyde, acetone, acrolein, and acetaldehyde. Paraffinic species are just ethane and methane. These products are similar to those reported in previous studies $[14,15]$. As pressure decreased, the consumption rate of iso-octane decreases which lowers the concentration of some species below the limit of detection by the GC. Therefore, the number of measured intermediate species decreased at lower pressure.

The comparison of product species measured in the experiment and predicted by the model are shown in Figs. 5-22 at 3,6 and 9 atm pressure. In all figures, the points are the experimental measurements and the lines the model predictions while solid lines correspond to solid symbols and dashed lines to open symbols. The model does tend to underpredict the overall reactivity at $3 \mathrm{~atm}$ but overall, there is good agreement between the model and experiment. Not only does the model predict quantitative agreement with the major measured products but the shape of the profiles also match very well. Therefore, we are confident that our interpretation of the important pathways leading to their formation is correct. In the following section we explain how we believe all of the major products are generated in the oxidation process.

Under all conditions of this study, fuel oxidation occurs via H-atom abstraction by hydroxyl radicals and to a much lesser extent by hydroperoxyl radicals.

$$
\begin{aligned}
\mathrm{iC}_{8} \mathrm{H}_{18}+\dot{\mathrm{O}} \mathrm{H} & \longrightarrow \mathrm{x} \dot{\mathrm{C}}_{8} \mathrm{H}_{17}+\mathrm{H}_{2} \mathrm{O} \\
\mathrm{iC}_{8} \mathrm{H}_{18}+\mathrm{HO}_{2} & \longrightarrow x \dot{\mathrm{C}}_{8} \mathrm{H}_{17}+\mathrm{H}_{2} \mathrm{O}_{2}
\end{aligned}
$$

In $\mathrm{x}_{8} \dot{\mathrm{H}}_{17}$, $\mathrm{x}$ refers to site $\mathrm{a}, \mathrm{b}, \mathrm{c}$ or $\mathrm{d}$ in Fig. 2. Because rates of abstraction of $\mathrm{H}$ atoms by hydroxyl radicals are not very site dependent (i.e. primary, secondary etc.) the formation of alkyl radicals occurs in the order $\mathrm{a}, \mathrm{d}, \mathrm{b}, \mathrm{c}$ with a ratio of 2.74:1.85:1.56:1 at 9 atm and $919 \mathrm{~K}$. Under these conditions, about four out of every five iso-octyl radicals decompose via $\beta$-scission to form an olefin and another smaller alkyl radical while the remaining one radical in every five adds to molecular oxygen to form octyl-peroxyl radicals. As described below, the products of $\beta$-scission mainly lead to isobutene, propene, and $\mathrm{C}_{7}$ olefins which compose a large fraction of the major products quantified experimentally.

\section{Hydrocarbon Product Formation}

Figs. 6-14 show the experimentally measured olefins formed together with the model predictions. It is reasonable to assume by the good agreement between model and experiment that the mechanism is predicting the major olefinic production routes correctly. Olefins are the main products formed in the oxidation process, of which isobutene $\left(\mathrm{iC}_{4} \mathrm{H}_{8}\right)$ is formed in highest concentrations followed by propene, $\left(\mathrm{C}_{3} \mathrm{H}_{6}\right)$. Figs. 6-8 indicate that the experimentally measured isobutene and propene profiles are well reproduced by the model. In the equation array below, we list the reactions responsible for isobutene and propene formation in order of decreasing importance.

$$
\begin{aligned}
& \dot{\mathrm{C}}_{8} \mathrm{H}_{17} \longrightarrow \mathrm{iC}_{4} \mathrm{H}_{8}+\mathrm{iC}_{4} \mathrm{H}_{9} \\
& \mathrm{c}_{8} \mathrm{H}_{17} \longrightarrow \dot{\mathrm{C}}_{4} \mathrm{H}_{8}+\mathrm{tC}_{4} \mathrm{H}_{9}
\end{aligned}
$$




$$
\begin{aligned}
\mathrm{i}, \mathrm{t}_{4} \mathrm{H}_{9}+\mathrm{O}_{2} & \longrightarrow \mathrm{iC}_{4} \mathrm{H}_{8}+\mathrm{HO}_{2} \\
\mathrm{iC}_{4} \mathrm{H}_{9} & \longrightarrow \mathrm{C}_{3} \mathrm{H}_{6}+\dot{\mathrm{C}}_{3} \\
\mathrm{~d} \dot{\mathrm{C}}_{8} \mathrm{H}_{17} & \longrightarrow \mathrm{C}_{3} \mathrm{H}_{6}+\text { neo } \dot{\mathrm{C}}_{5} \mathrm{H}_{11} \\
\mathrm{i}_{4} \mathrm{H}_{8} \mathrm{OOH}-\mathrm{i} & \longrightarrow \mathrm{C}_{3} \mathrm{H}_{6}+\mathrm{CH}_{2} \mathrm{O}+\dot{\mathrm{OH}}
\end{aligned}
$$

In $\mathrm{iC}_{4} \mathrm{H}_{8} \mathrm{OOH}-\mathrm{i}$ the hydroperoxyl group is attached to one of the substituted methyl groups while there is a radical site on one of the other two methyl groups.

Methane $\left(\mathrm{CH}_{4}\right)$ is generated by the reaction of methyl radicals with hydroperoxyl radical and with the fuel, Figs 6-8.

$$
\begin{aligned}
\dot{\mathrm{CH}}_{3}+\mathrm{HO}_{2} & \longrightarrow \mathrm{CH}_{4}+\mathrm{O}_{2} \\
\mathrm{iC}_{8} \mathrm{H}_{18}+\dot{\mathrm{C}} \mathrm{II}_{3} & \longrightarrow x \dot{\mathrm{C}}_{8} \mathrm{H}_{17}+\mathrm{CH}_{4}
\end{aligned}
$$

The agreement between the predicted and measured concentrations is very good at all pressures. -

Significant quantities of the $\mathrm{C}_{7}$ olefins are also formed including 4,4-dimethyl-pent-2ene $\left(\mathrm{oC}_{7} \mathrm{H}_{14}\right), 2,4$-dimethyl-pent-2-ene, $\left(\mathrm{yC}_{7} \mathrm{H}_{14}\right), 2,4$-dimethyl-pent-1-ene $\left(\mathrm{xC}_{7} \mathrm{H}_{14}\right)$ and 4,4dimethyl-pent-1-ene $\left(\mathrm{pC}_{7} \mathrm{H}_{14}\right)$, Figs. 9-11.

$$
\begin{aligned}
& \mathrm{b} \dot{\mathrm{C}}_{8} \mathrm{H}_{17} \longrightarrow \mathrm{oC}_{7} \mathrm{H}_{14}+\dot{\mathrm{C}} \mathrm{H}_{3} \\
& \mathrm{~b} \dot{\mathrm{C}}_{8} \mathrm{H}_{17} \longrightarrow \mathrm{yC}_{7} \mathrm{H}_{14}+\dot{\mathrm{C}} \mathrm{H}_{3} \\
& \mathrm{a} \dot{\mathrm{C}}_{8} \mathrm{H}_{17} \longrightarrow \mathrm{xC}_{7} \mathrm{H}_{14}+\dot{\mathrm{C}} \mathrm{H}_{3} \\
& \mathrm{~d} \dot{\mathrm{C}}_{8} \mathrm{H}_{17} \longrightarrow \mathrm{pC}_{7} \mathrm{H}_{14}+\dot{\mathrm{C}} \mathrm{H}_{3}
\end{aligned}
$$

The model indicates that the $\mathrm{C}_{7}$ olefins are formed almost exclusively by $\beta$-scission of iso-octyl radicals under the conditions of this study. Note that the decomposition of 2,1,4trimethyl-pent-3-yl radical, $\left(\mathrm{b} \dot{\mathrm{C}}_{8} \mathrm{H}_{17}\right)$, leads to the formation of almost equal quantities of 2,4- and 4,4-dimethyl-pent-2-ene. $\mathrm{C}_{7}$ olefins can also be formed through low temperature reaction paths. The model indicates that very small amounts $(\approx 5 \%)$ are generated from octyl-hydroperoxide radical $\beta$-scission.

$$
\begin{aligned}
& \mathrm{d} \dot{\mathrm{C}}_{8} \mathrm{H}_{16} \mathrm{OOH}-\mathrm{b} \longrightarrow \mathrm{oC}_{7} \mathrm{H}_{14}+\mathrm{CH}_{2} \mathrm{O}+\dot{\mathrm{O}} \mathrm{H} \\
& \mathrm{aC}_{8} \mathrm{H}_{16} \mathrm{OOH}-\mathrm{b} \longrightarrow \mathrm{yC}_{7} \mathrm{H}_{14}+\mathrm{CH}_{2} \mathrm{O}+\dot{\mathrm{OH}} \\
& \dot{a}_{8} \mathrm{H}_{16} \mathrm{OOH}-\mathrm{a} \longrightarrow \mathrm{xC}_{7} \mathrm{H}_{14}+\mathrm{CH}_{2} \mathrm{O}+\dot{\mathrm{O} H} \\
& \mathrm{~d} \dot{\mathrm{C}}_{8} \mathrm{H}_{16} \mathrm{OOH}-\mathrm{d} \longrightarrow \mathrm{pC}_{7} \mathrm{H}_{14}+\mathrm{CH}_{2} \mathrm{O}+\dot{\mathrm{O} H}
\end{aligned}
$$

In $\mathrm{d}_{8} \mathrm{H}_{16} \mathrm{OOH}-\mathrm{b}$, 'd' refers to the site at which the hydroperoxyl group is attached and ' $b$ ' to the radical site on iso-octane. Under all conditions the model predictions match the experimental profiles very well. At 9 atm and $919 \mathrm{~K}$, Fig. 11, both ${ }_{0} \mathrm{C}_{7} \mathrm{H}_{14}$ and $\mathrm{yC}_{7} \mathrm{H}_{14}$ are slightly overpredicted late in the experiment. However, early decline in the $\mathrm{yC}_{7} \mathrm{H}_{14}$ profile compared to the $\mathrm{oC}_{7} \mathrm{H}_{14}$ profile is reproduced by the model. 
There are various other hydrocarbon species produced, including allene $\left(\mathrm{C}_{3} \mathrm{H}_{4}\right.$-a), ethylene $\left(\mathrm{C}_{2} \mathrm{H}_{4}\right)$, ethane $\left(\mathrm{C}_{2} \mathrm{H}_{6}\right)$, 2,4,4-trimethyl-pent-1-ene $\left(\mathrm{jC}_{8} \mathrm{H}_{16}\right)$, and 2-methyl-but-1-ene, $\left(\mathrm{aC}_{5} \mathrm{H}_{10}\right)$, Figs. 12-14. Allene is formed in appreciable concentrations and is predicted to be generated from the reaction of methyl-allyl radical with molecular oxygen via the overall reaction:

$$
\mathrm{i}_{4} \mathrm{H}_{7}+\mathrm{O}_{2} \longrightarrow \mathrm{C}_{3} \mathrm{H}_{4}-\mathrm{a}+\mathrm{CH}_{2} \mathrm{O}+\dot{\mathrm{O}} \mathrm{H}
$$

Small concentrations of 2,4,4-trimethyl-pent-1-ene $\left(\mathrm{jC}_{8} \mathrm{H}_{16}\right)$ were measured and this olefin is predicted to be formed from the $\beta$-scission of a hydroperoxy-octyl radical:

$$
\begin{aligned}
& \mathrm{d}_{\mathrm{C}_{8} \mathrm{H}_{16} \mathrm{OOH}-\mathrm{c}} \longrightarrow \mathrm{jC}_{8} \mathrm{H}_{16}+\mathrm{HO}_{2} \\
& \mathrm{~b} \dot{\mathrm{C}}_{8} \mathrm{H}_{16} \mathrm{OOH}-\mathrm{c} \longrightarrow \mathrm{jC}_{8} \mathrm{H}_{16}+\mathrm{HO}_{2}
\end{aligned}
$$

In addition, 2,4,4-trimethyl-pent-2-ene $\left(\mathrm{iC}_{8} \mathrm{H}_{16}\right)$ was identified at 9 atm and $919 \mathrm{~K}$. Under these conditions, both $\mathrm{i}$ - and $\mathrm{jC}_{8} \mathrm{H}_{16}$ are slightly overpredicted by the model, Fig. $14 . \mathrm{iC}_{8} \mathrm{H}_{16}$ was not quantified at 3 and 6 atm but its predicted profile is provided in Fig. 13.

2-methyl-but-1-ene $\left(\mathrm{aC}_{5} \mathrm{H}_{10}\right)$ is predicted to be formed by the reaction of methyl-allyl with methyl radicals, although it is always very much underpredicted by the model indicating that there may be an alternative route to its formation.

$$
\mathrm{i}_{4} \mathrm{H}_{7}+\dot{\mathrm{C}} \mathrm{H}_{3} \longrightarrow \mathrm{aC}_{5} \mathrm{H}_{10}
$$

In Figs. 12-14 the lowest solid line correcsponds to the model predicted 2-methyl-but-1-ene concentrations.

\section{Oxygenated Product Formation}

Of the oxygenates, acetone $\left(\mathrm{CH}_{3} \mathrm{COCH}_{3}\right)$, methacrolein $\left(\mathrm{iC}_{3} \mathrm{H}_{5} \mathrm{CHO}\right)$ and isobuteraldehyde $\left(\mathrm{iC}_{3} \mathrm{H}_{7} \mathrm{CHO}\right)$ are formed in relatively high concentrations, Figs. 15-17. Acetone is predicted to be formed through the Waddington mechanism $[16,17]$ mainly from isobutene, Fig. 3 with a small quantity formed from the $\mathrm{C}_{7}$ olefins at high fuel conversion.

Methallyl radicals can react with hydroperoxyl radicals creating methallyl-oxyl radicals which decompose to yield methacrolein and hydrogen atom. As these experiments were performed under very lean conditions some methallyl-oxyl radicals also react with molecular oxygen to produce methacrolein and hydroperoxyl radicals.

$$
\begin{aligned}
\mathrm{iC}_{4} \mathrm{H}_{7} \mathrm{O} & \longrightarrow \mathrm{iC}_{3} \mathrm{H}_{5} \mathrm{CHO}+\dot{\mathrm{H}} \\
\mathrm{iC}_{4} \mathrm{H}_{7} \dot{\mathrm{O}}+\mathrm{O}_{2} & \longrightarrow \mathrm{iC}_{3} \mathrm{H}_{5} \mathrm{CHO}+\mathrm{HO}_{2} \\
\mathrm{~b}_{8} \mathrm{H}_{16} \mathrm{OOH}-\mathrm{a} & \longrightarrow \mathrm{iC}_{3} \mathrm{H}_{7} \mathrm{CHO}+\mathrm{iC}_{4} \mathrm{H}_{8}+\dot{\mathrm{OH}} \\
\mathrm{iC}_{4} \mathrm{H}_{8} \mathrm{O} & \longrightarrow \mathrm{iC}_{3} \mathrm{H}_{7} \mathrm{CHO} \\
\mathrm{zC}_{7} \mathrm{H}_{14} \mathrm{O}-\mathrm{yO}_{2} \mathrm{H} & \longrightarrow \mathrm{iC}_{3} \mathrm{H}_{7} \mathrm{CHO}+\mathrm{CH}_{3} \mathrm{COCH} 3+\dot{\mathrm{OH}} \\
\mathrm{yC}_{7} \mathrm{H}_{14} \mathrm{O}-\mathrm{zO}_{2} \mathrm{H} & \longrightarrow \mathrm{iC}_{3} \mathrm{H}_{7} \mathrm{CHO}+\mathrm{CH}_{3} \mathrm{COCH} 3+\dot{\mathrm{OH}}
\end{aligned}
$$




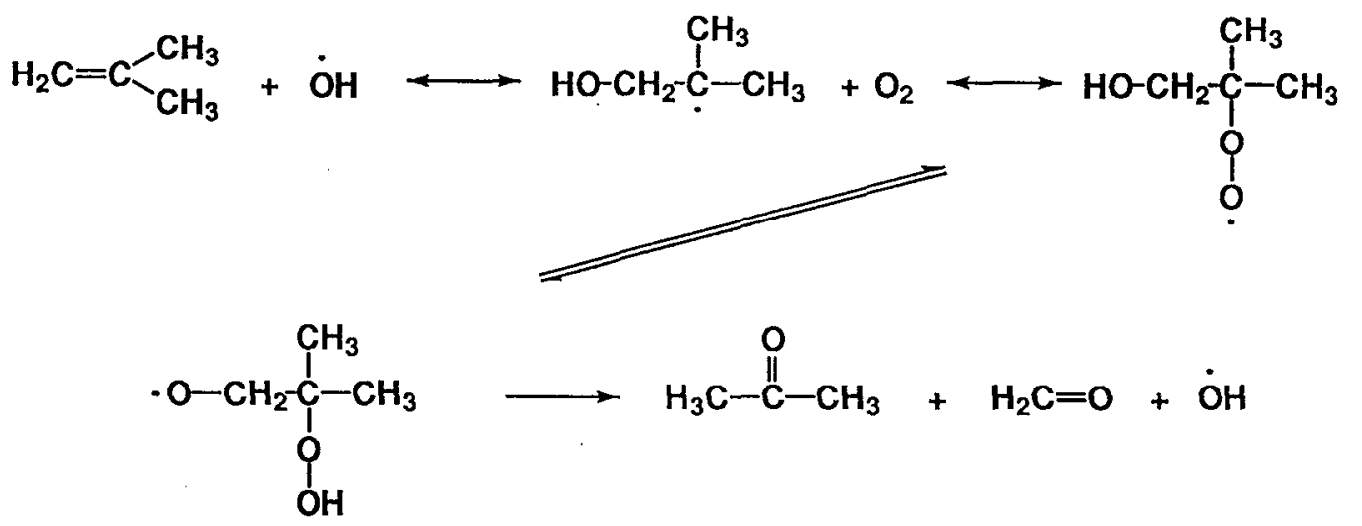

Figure 3: Formation of acetone via the Waddington mechanism.

Isobuteraldehyde is mainly produced from the $\beta$-scission of 2,4,4-trimethyl-3-hydroperoxypent-1-yl radical ( $\left.\mathrm{bC}_{8} \mathrm{H}_{1} 6 \mathrm{OOH}-\mathrm{a}\right)$ and also from the decomposition of isobutene oxide [18]. At higher fuel conversion some isobuteraldehyde (and acetone) is also produced from 2,4dimethyl-pent-2-ene via the waddington mechanism.

Other various aldehydes were quantified including, acetaldehyde $\left(\mathrm{CH}_{3} \mathrm{CHO}\right)$, acrolein $\left(\mathrm{C}_{2} \mathrm{H}_{3} \mathrm{CHO}\right)$, and 2,2-dimethyl-propanal $\left(\mathrm{tC}_{4} \mathrm{H}_{9} \mathrm{CHO}\right)$, Figs. 18-19. Acetaldehyde is formed from the oxidation of propene through the Waddington mechanism by analogy to the formation of acetone from isobutene as described above.

Acrolein is produced by analogy with methacrolein from the allyl-oxy radical.

$$
\begin{aligned}
\mathrm{C}_{3} \mathrm{H}_{5} \dot{\mathrm{O}} & \longrightarrow \mathrm{C}_{2} \mathrm{H}_{3} \mathrm{CHO}+\dot{\mathrm{H}} \\
\mathrm{C}_{3} \mathrm{H}_{5} \dot{\mathrm{O}}+\mathrm{O}_{2} & \longrightarrow \mathrm{C}_{2} \mathrm{H}_{3} \mathrm{CHO}+\mathrm{HO}_{2}
\end{aligned}
$$

2,2-dimethyl-propanal is predicted to be formed directly from the iso-octane low temperature mechanism mainly from 2,4,4-trimethyl-3-hydroperoxyl-pent-1-yl radical $\left(\mathrm{b} \dot{\mathrm{C}}_{8} \mathrm{H}_{16} \mathrm{OOH}-\right.$ d), with a smaller quantity being produced from 2,4,4-trimethyl-3-hydroperoxyl-1-pentanal $\left(\mathrm{iC}_{8} \mathrm{ketdb}\right)$. In addition, a small quantity is also produced via the waddington mechanism from $\mathrm{oC}_{7} \mathrm{H}_{14}$.

$$
\begin{aligned}
& \mathrm{b} \dot{\mathrm{C}}_{8} \mathrm{H}_{16} \mathrm{OOH}-\mathrm{d} \longrightarrow \mathrm{tC}_{4} \mathrm{H}_{9} \mathrm{CHO}+\mathrm{C}_{3} \mathrm{H}_{6}+\dot{\mathrm{O}} \mathrm{H} \\
& \mathrm{iC}_{8} \text { ketdb } \longrightarrow \mathrm{tC}_{4} \mathrm{H}_{9} \mathrm{CHO}+\mathrm{CH}_{3} \dot{\mathrm{C}} \mathrm{HCHO}+\dot{\mathrm{O}} \mathrm{H} \\
& \mathrm{pC}_{7} \mathrm{H}_{14} \mathrm{O}-\mathrm{oO}_{2} \mathrm{H} \longrightarrow \mathrm{tC}_{4} \mathrm{H}_{9} \mathrm{CHO}+\mathrm{CH}_{3} \mathrm{CHO}+\dot{\mathrm{O}} \mathrm{H} \\
& \mathrm{oC}_{7} \mathrm{H}_{14} \mathrm{O}-\mathrm{pO}_{2} \mathrm{H} \longrightarrow \mathrm{tC}_{4} \mathrm{H}_{9} \mathrm{CHO}+\mathrm{CH}_{3} \mathrm{CHO}+\dot{\mathrm{O}} \mathrm{H}
\end{aligned}
$$

Relatively high concentrations of cyclic ethers are measured including 2,2,4,4-tetramethyltetrahydro-furan ( $\mathrm{TMTHF}, \mathrm{iC}_{8}$ eterac), isobutene oxide $\left(\mathrm{iC}_{4} \mathrm{H}_{8} \mathrm{O}\right)$, 2-isopropyl-3,3-dimethyl oxetane $\left(\mathrm{iC}_{8}\right.$ eterab) and 2-tert-butyl-3-methyl oxetane ( $\mathrm{iC}_{8}$ eterbd), Figs. 20-22. In Figs. 21 
and 22 the lower dotted line corresponds to $\mathrm{iC}_{8}$ eterbd. At $3 \mathrm{~atm}$ the model underpredicts the measured $\mathrm{C}_{8}$ cyclic ether profiles, (Fig. 20), but very low concentrations of these species are measured under these conditions. Very good agreement is observed between measured and predicted profiles at 6 and 9 atm, Figs. 21 and 22 .

In addition to the experimentally measured cyclic ethers, the mechanism also predicts detectible concentrations of 2,3-epoxy-2,4,4-trimethyl-pentane $\left(\mathrm{iC}_{8}\right.$ eterbc) which is included as the lower dotted line in Fig. 20 and the lowest solid line in Figs. 20-22. This product was also reported by Leppard [15] in his motored engine study. The $\mathrm{C}_{8}$ cyclic ether species are predicted to be formed from the corresponding hydroperoxy-octyl radical, see for example Fig. 4.

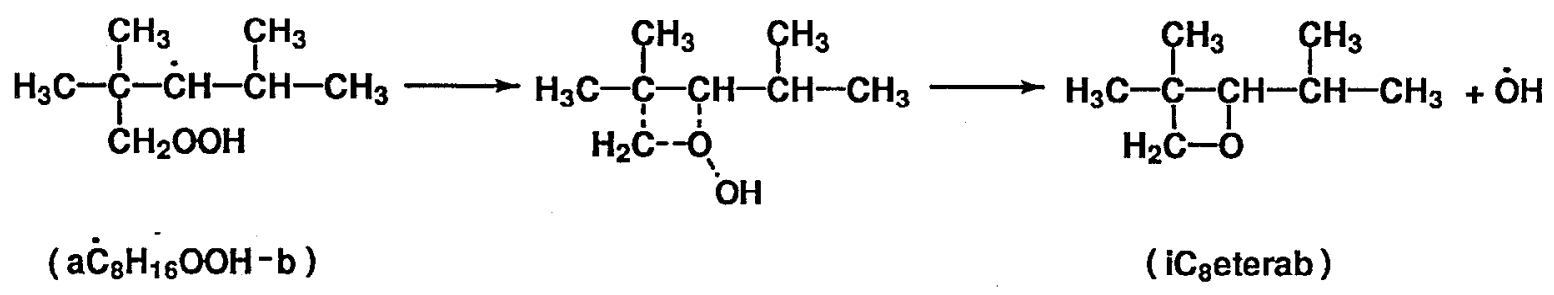

Figure 4: Formation of 2-isopropyl-3,3-dimethyl oxetane.

\section{Acknowledgement}

This work was performed under the auspices of the U.S. Department of Energy by the Lawrence Livermore National Laboratory under contract No. W-7405-ENG-48. 


\section{References}

[1] Dryer, F. L. and Brezinsky, K. W., Combust. Sci. Technol. 45:199-212 (1986).

[2] Hunter, T. B., Ph.D. thesis, the Pennsylvania State University (1994).

[3] Jensen, T. E., Siegl, W. O., Richert, J. F. O., Loo, J. F., Prostak, A., Lipari, F. and Sigsby, J. E., Society of Automotive Engineers publication SAE-920320 (1992).

[4] Siegl, W. O., Richert, J. F. O., Jensen, T. E., Schuetzle, D., Swarin, S. J., Loo, J. F., Prostak, A., Nagy, D. and Schlenker, A. M., Society of Automotive Engineers publication SAE-930142 (1993).

[5] Lund, C. M. and Chase, L., "HCT - A General Computer Program for Calculating Time-Dependent Phenomena Involving One-Dimensional Hydrodynamics, Transport, and Detailed Chemical Kinetics," Lawrence Livermore National Laboratory report UCRL-52504, revised (1995).

[6] Westbrook, C. K., Warnatz, J., and Pitz, W. J., Twenty-Second Symposium (International) on Combustion., pp. 893-901, The Combustion Institute, Pittsburgh, 1988.

[7] Westbrook, C. K., Pitz, W. J., and Leppard, W. R., Society of Automotive Engineers publication SAE-912314 (1991).

[8] Chevalier, C., Pitz, W. J., Warnatz, J., Westbrook, C. K., and Melenk, H., TwentyFourth Symposium (International) on Combustion., pp. 92-101, The Combustion Institute, Pittsburgh, 1992.

[9] Westbrook, C. K., and Pitz, W. J., "A Chemical Kinetic Mechanism for the Oxidation of Paraffinic Hydrocarbons Needed for Primary Reference fuels". Western States Section/ The Combustion Istitute, Spring Meeting, (1993).

[10] Curran, H. J., Gaffuri, P., Pitz, W. J., Westbrook, C. K., Callahan, C., Dryer, F. L., and Held, T., Central States/Western States/Mexican Ntl. Sections Comb. Inst. 263, (1995).

[11] Curran, H. J.; Gaffuri, P.; Pitz, W. J.; Westbrook, C. K.

"A Comprehensive Modeling Study of n-Heptane Combustion."

Combust. and Flame, 114:149-177, 1998.

[12] Ritter, E. R. and Bozzelli, J. W., Int. J. Chem. Kinet. 23:767 (1991).

[13] Lay, T. and Bozzelli, J. W., Chemical and Physical Processes in Combustion, The Eastern States Section of the Combustion Institute, Paper \# 100 (1-4), (1993).

[14] Maynard, J. B., Legate, C. E. and Graiff, L. B., Combust. and Flame, 11:155-166 (1967).

[15] Leppard, W. R., Society of Automotive Engineers publication SAE-922325, (1992).

[16] Ray, D. J. M.; Diaz, R. R. and Waddington, D. J., Fourteenth Symposium (International) on Combustion., pp. 259, The Combustion Institute, Pittsburgh, 1973.

[17] Ray, D. J. M. and Waddington, D. J., Combust. Flame 20:327 (1973).

[18] Flowers, M. C. and Parker, R. M. Intl. J. Chem. kinet. 3:443 (1971). 


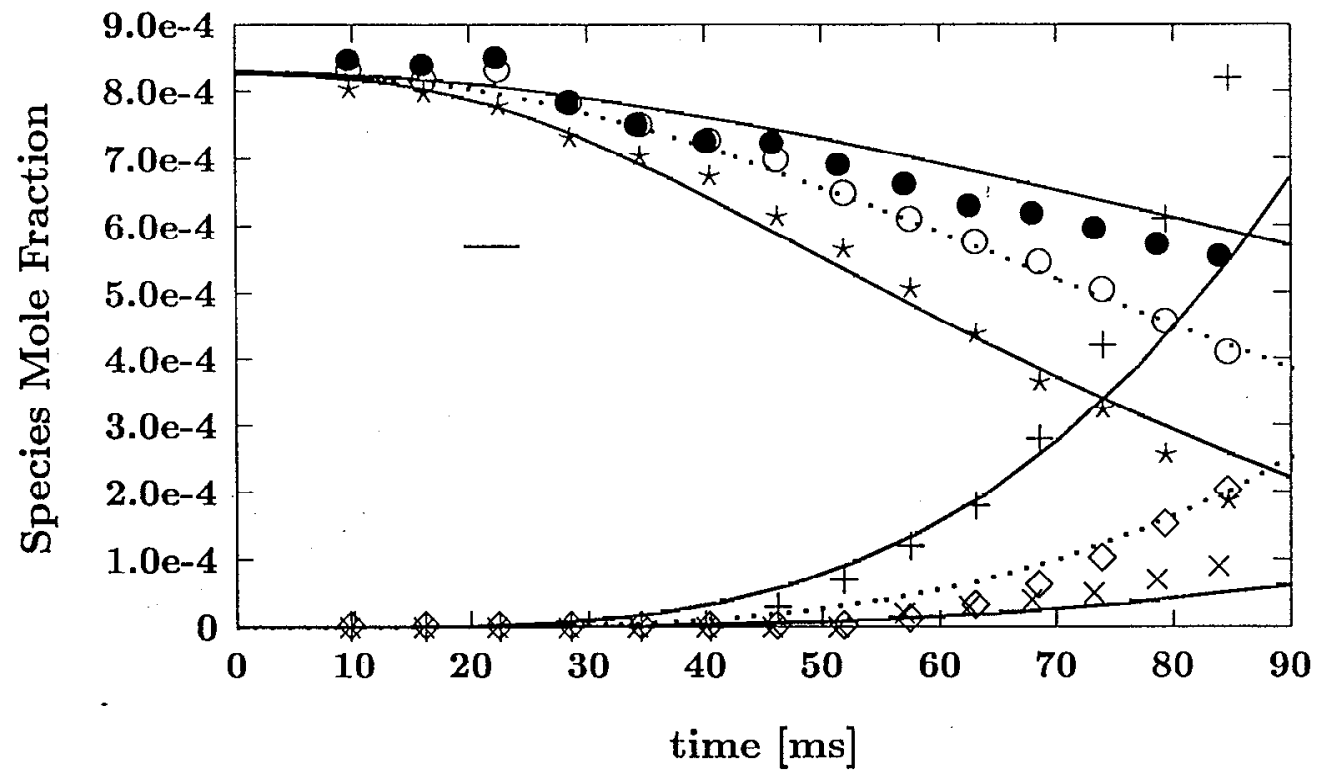

Figure 5: $\mathrm{iC}_{8} \mathrm{H}_{18}$ and $\mathrm{CO}$ profiles for three different mixtures. $3 \mathrm{~atm}, 930 \mathrm{~K}: \bullet \mathrm{iC}_{8} \mathrm{H}_{18}, \times$ $\mathrm{CO} ; 6 \mathrm{~atm}, 925 \mathrm{~K}$ : $\circ \mathrm{iC}_{8} \mathrm{H}_{18}, \diamond \mathrm{CO} ; 9$ atm $919 \mathrm{~K}: \star \mathrm{iC}_{8} \mathrm{H}_{18}$, + CO. Dashed lines correspond to open symbols.

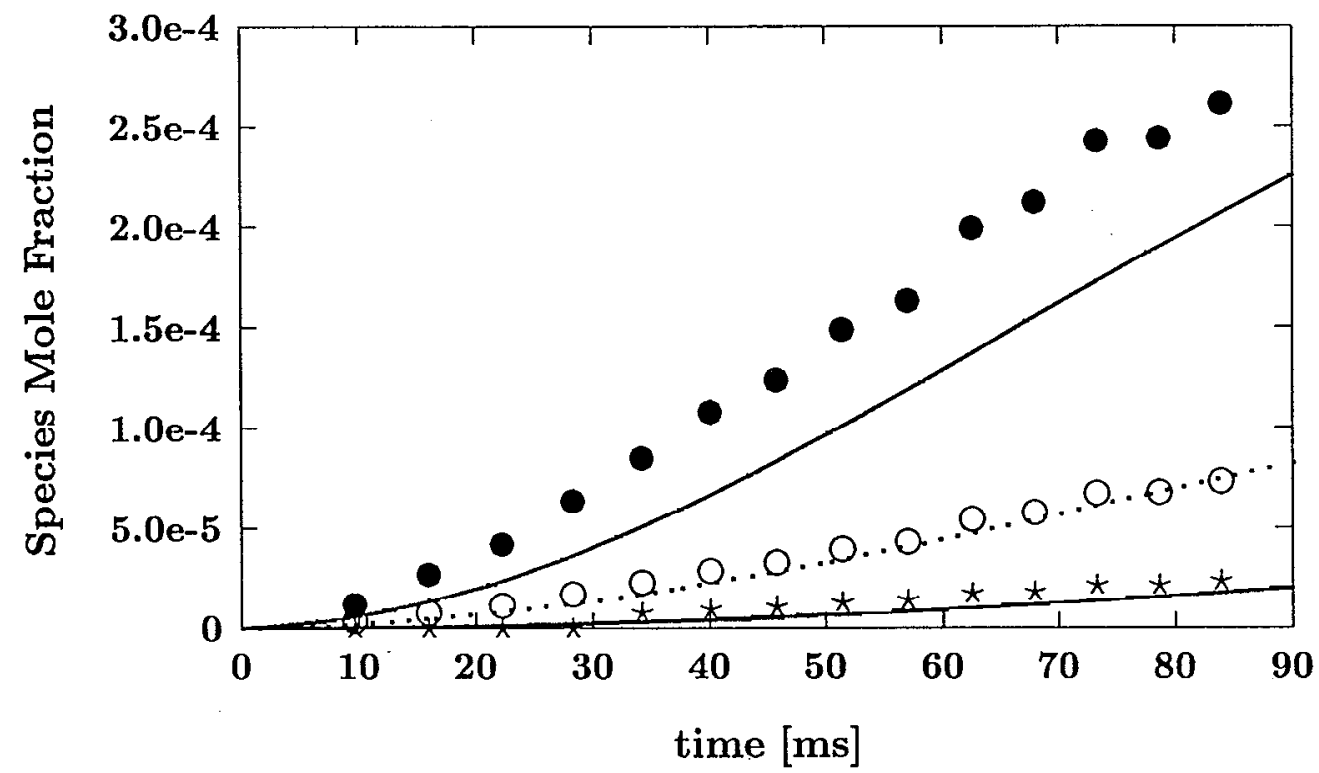

Figure 6: $0.083 \% \mathrm{iC}_{8} \mathrm{H}_{18}, \phi=0.05, \mathrm{~N}_{2}$ diluent at 3 atm and $930 \mathrm{~K}: \bullet \mathrm{iC}_{4} \mathrm{H}_{8}, \circ \mathrm{C}_{3} \mathrm{H}_{6}, \star \mathrm{CH}_{4}$. Dashed lines correspond to open symbols. 


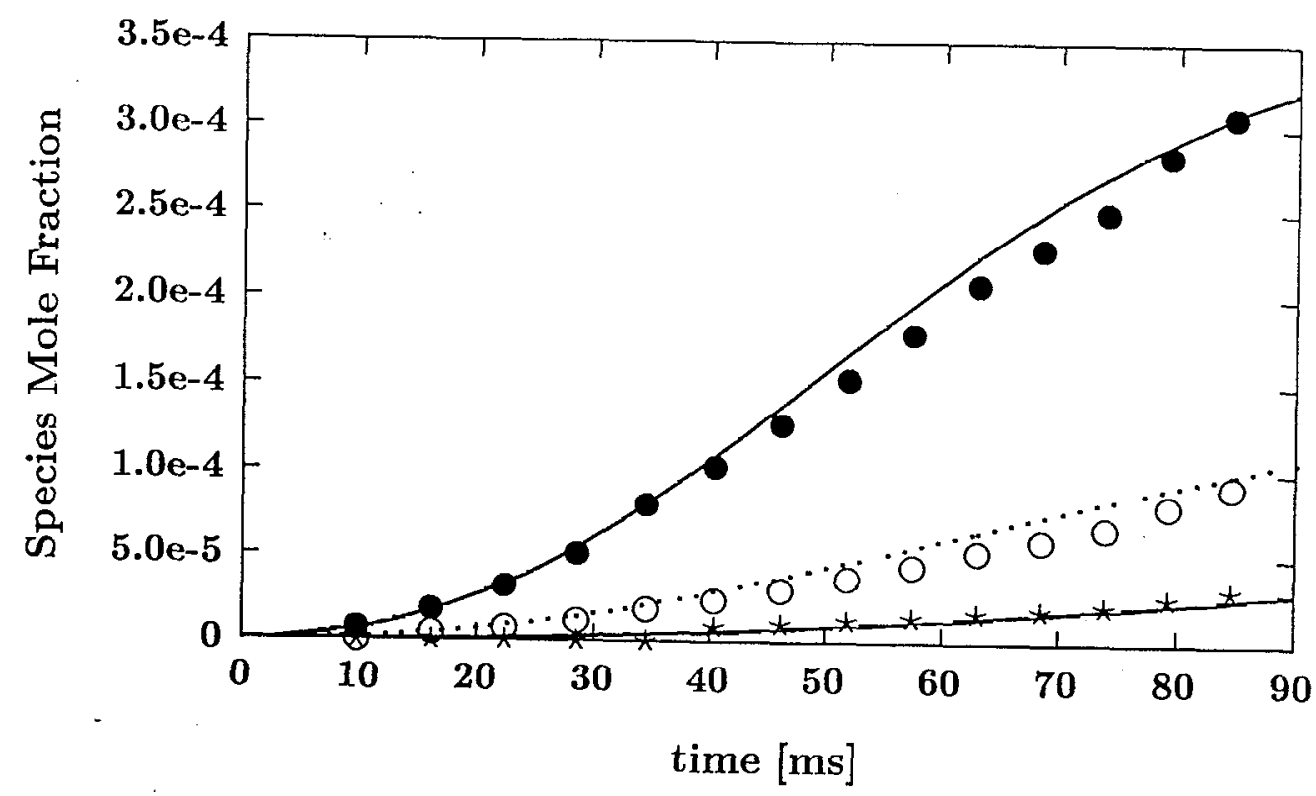

Figure 7: $0.083 \% \mathrm{iC}_{8} \mathrm{H}_{18}, \phi=0.05, \mathrm{~N}_{2}$ diluent at 6 atm and $925 \mathrm{~K}: \bullet \mathrm{iC}_{4} \mathrm{H}_{8}, \circ \mathrm{C}_{3} \mathrm{H}_{6}, \star \mathrm{CH}_{4}$. Dashed lines correspond to open symbols.

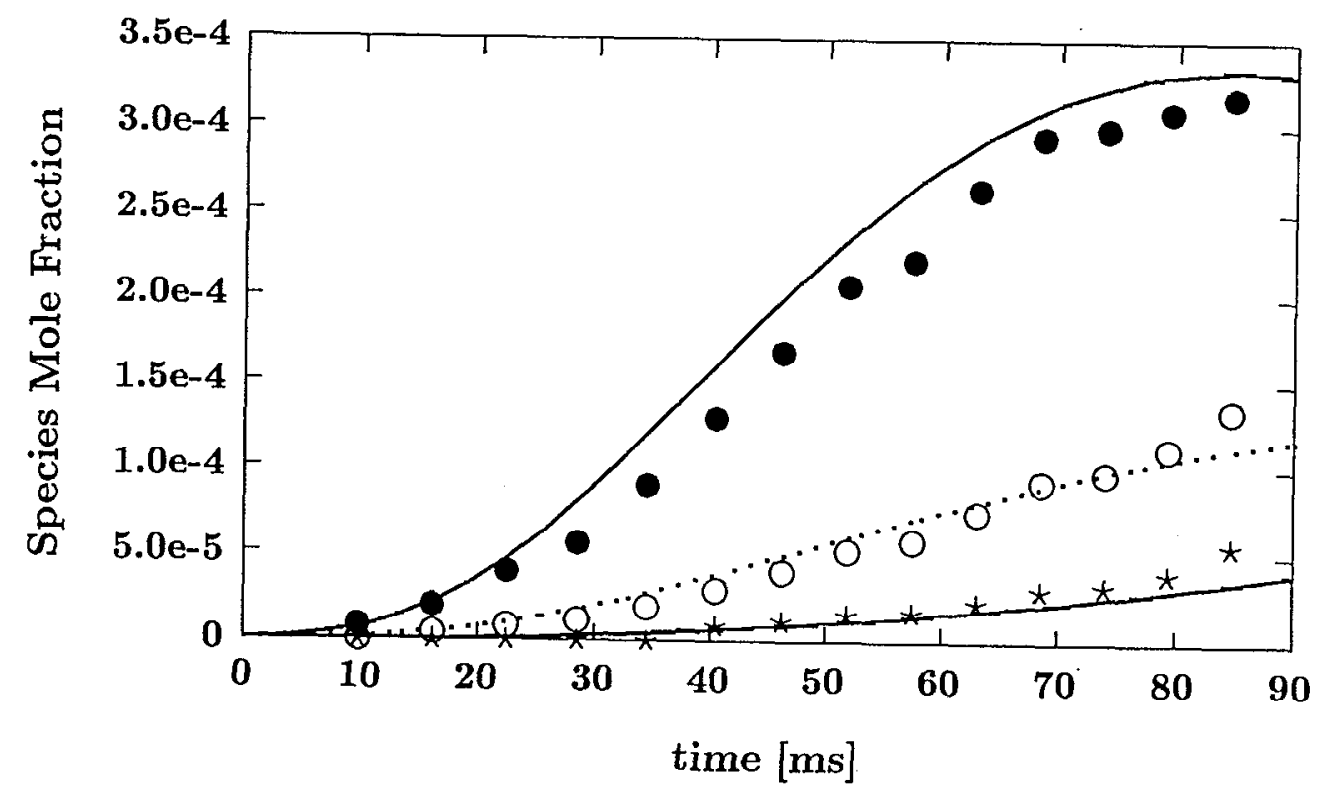

Figure 8: $0.0825 \% \mathrm{iC}_{8} \mathrm{H}_{18}, \phi=0.05, \mathrm{~N}_{2}$ diluent at 9 atm and $919 \mathrm{~K}: \bullet \mathrm{iC}_{4} \mathrm{H}_{8}, \circ \mathrm{C}_{3} \mathrm{H}_{6}$, * $\mathrm{CH}_{4}$. Dashed lines correspond to open symbols. 


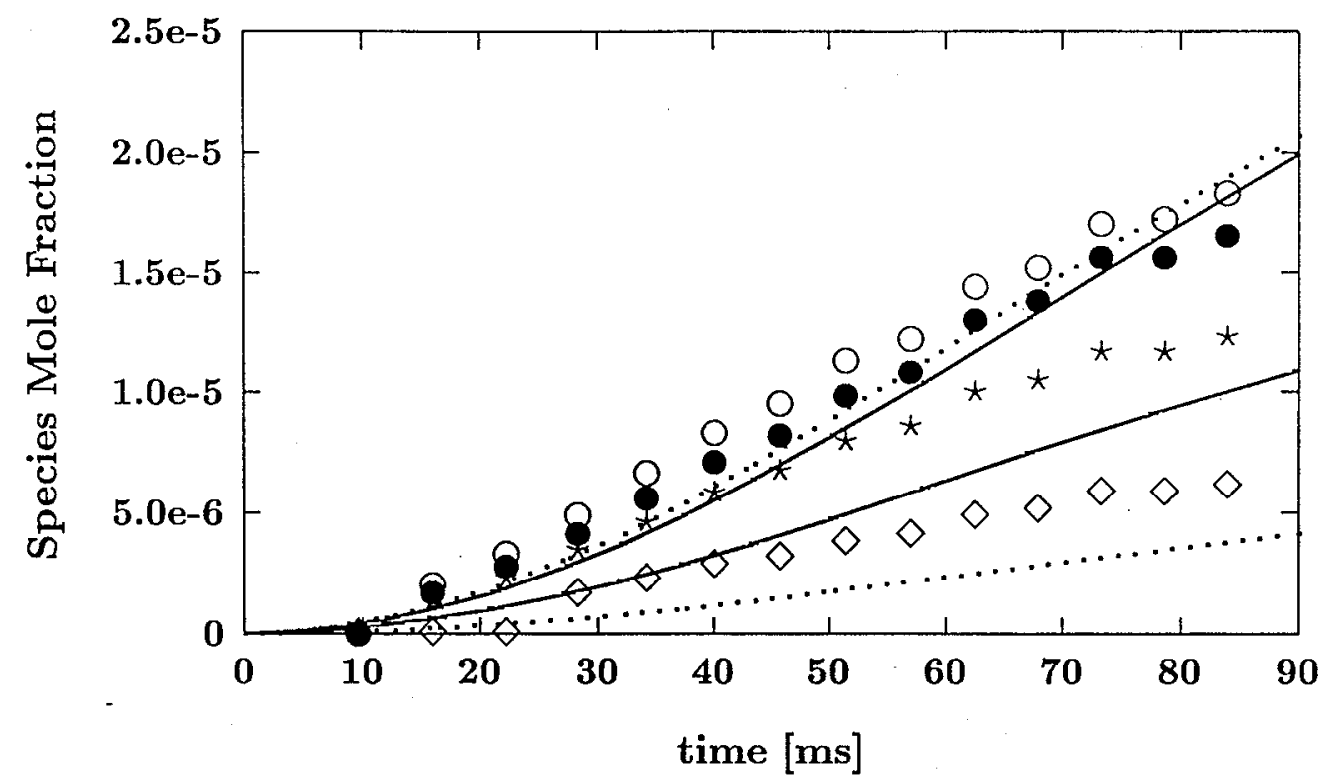

Figure 9: $0.083 \% \mathrm{iC}_{8} \mathrm{H}_{18}, \phi=0.05, \mathrm{~N}_{2}$ diluent at 3 atm and $930 \mathrm{~K}: \bullet \circ \mathrm{C}_{7} \mathrm{H}_{14}, \circ \mathrm{yC}_{7} \mathrm{H}_{14}$, $\mathrm{xC}_{7} \mathrm{H}_{14}, \diamond \mathrm{pC}_{7} \mathrm{H}_{14}$. Dashed lines correspond to open symbols.

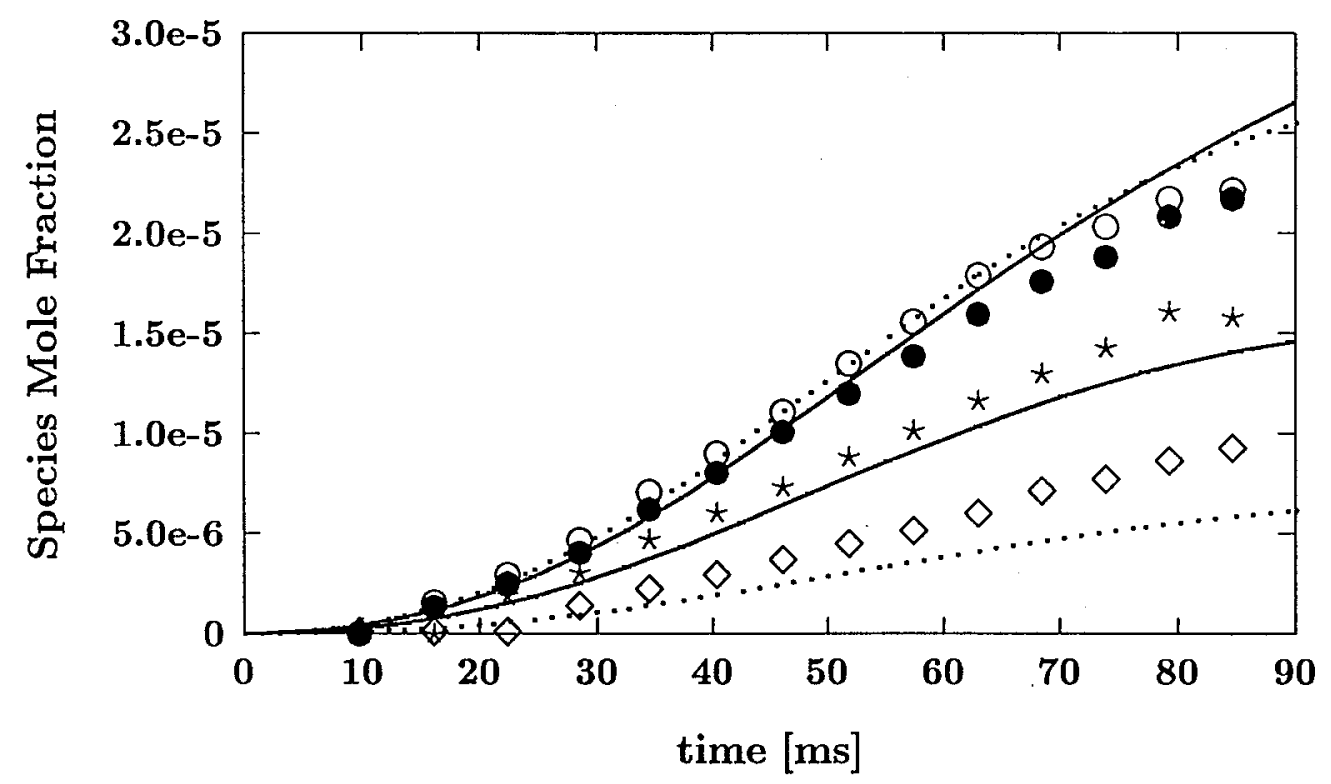

Figure 10: $0.083 \% \mathrm{iC}_{8} \mathrm{H}_{18}, \phi=0.05, \mathrm{~N}_{2}$ diluent at 6 atm and $925 \mathrm{~K}: \bullet \circ \mathrm{oC}_{7} \mathrm{H}_{14}, \circ \mathrm{yC}_{7} \mathrm{H}_{14}$, $\mathrm{xC}_{7} \mathrm{H}_{14}, \diamond \mathrm{pC}_{7} \mathrm{H}_{14}$. Dashed lines correspond to open symbols. 


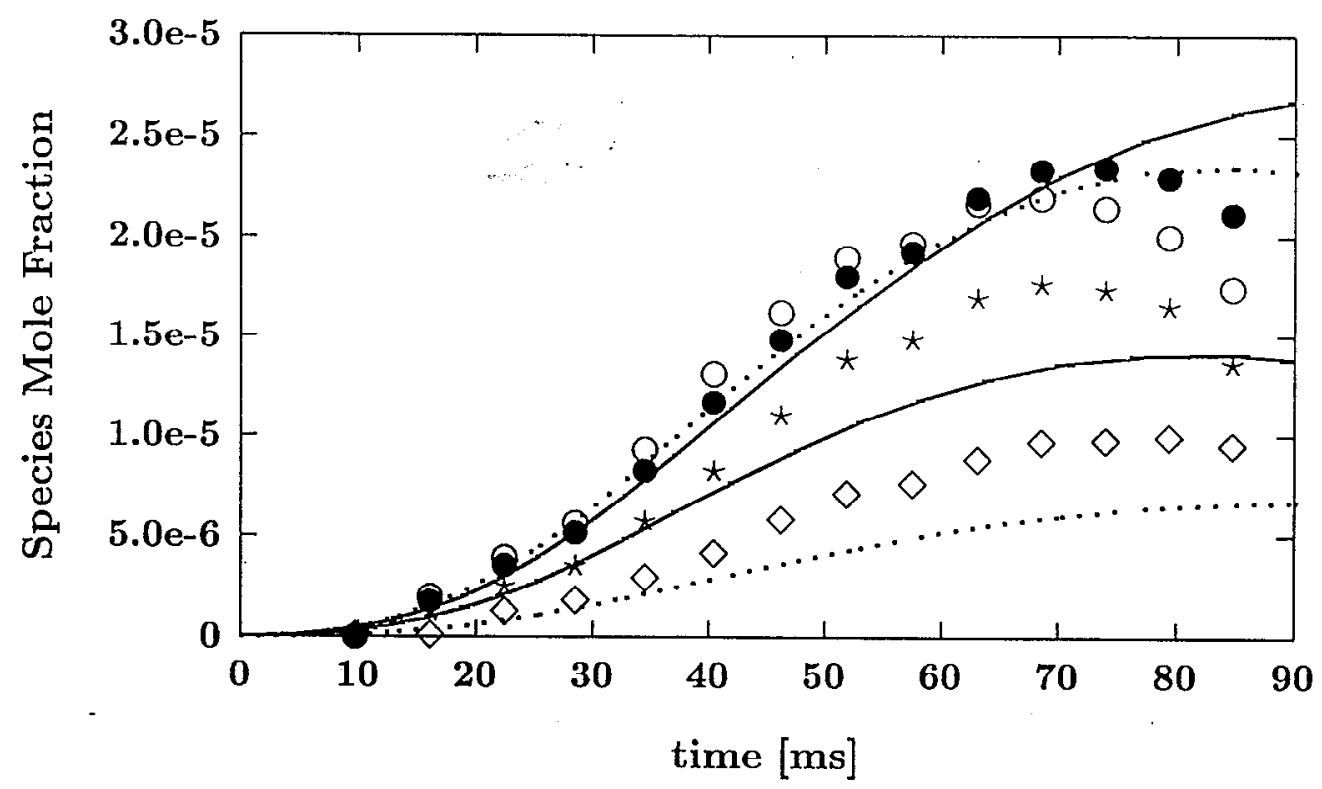

Figure 11: $0.0825 \% \mathrm{iC}_{8} \mathrm{H}_{18}, \phi=0.05, \mathrm{~N}_{2}$ diluent at 9 atm and $919 \mathrm{~K}: \bullet \mathrm{oC}_{7} \mathrm{H}_{14}, \circ \mathrm{yC}_{7} \mathrm{H}_{14}$, $\star \mathrm{xC}_{7} \mathrm{H}_{14}, \diamond \mathrm{pC}_{7} \mathrm{H}_{14}$. Dashed lines correspond to open symbols.

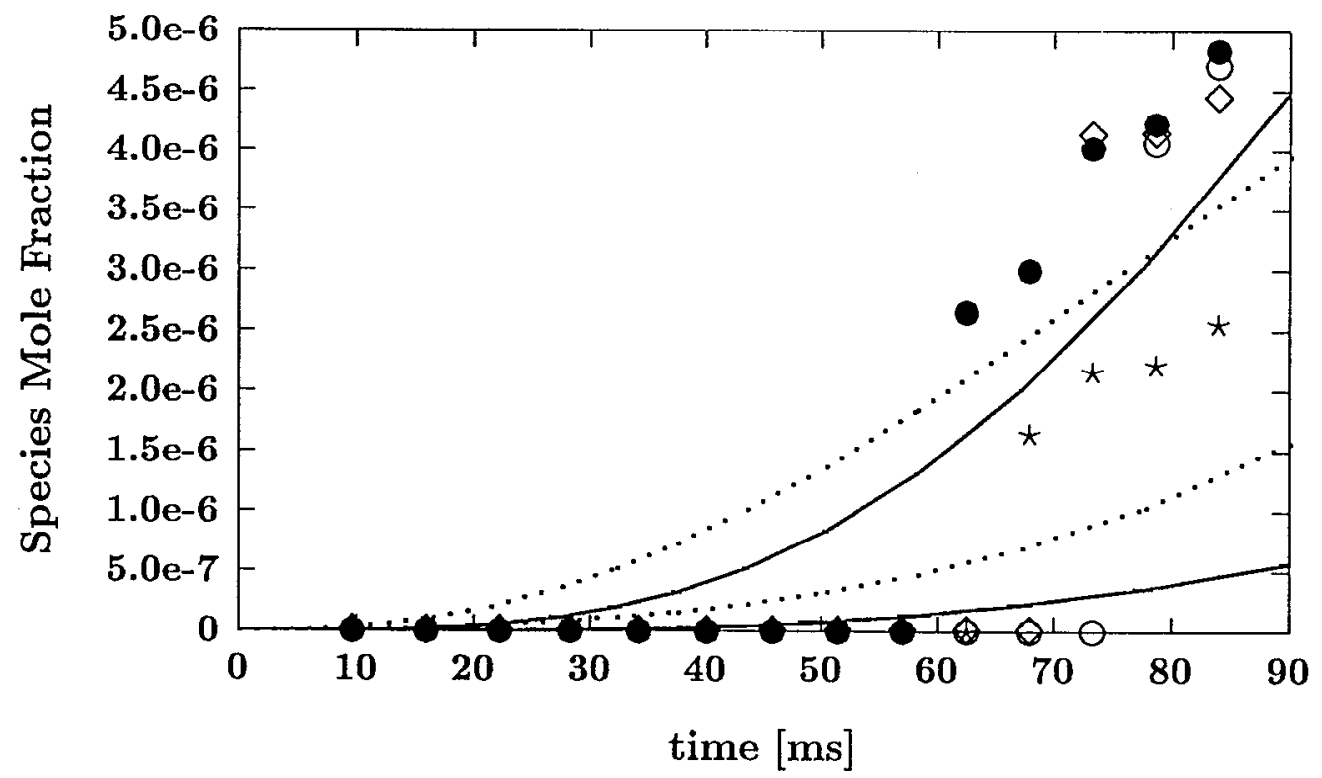

Figure 12: $0.083 \% \mathrm{iC}_{8} \mathrm{H}_{18}, \phi=0.05, \mathrm{~N}_{2}$ diluent at 3 atm and $930 \mathrm{~K}: \bullet \mathrm{C}_{3} \mathrm{H}_{4}-\mathrm{a}, \circ \mathrm{C}_{2} \mathrm{H}_{4}, \star$ $\mathrm{aC}_{5} \mathrm{H}_{10}, \diamond \mathrm{C}_{2} \mathrm{H}_{6}$. Dashed lines correspond to open symbols. 


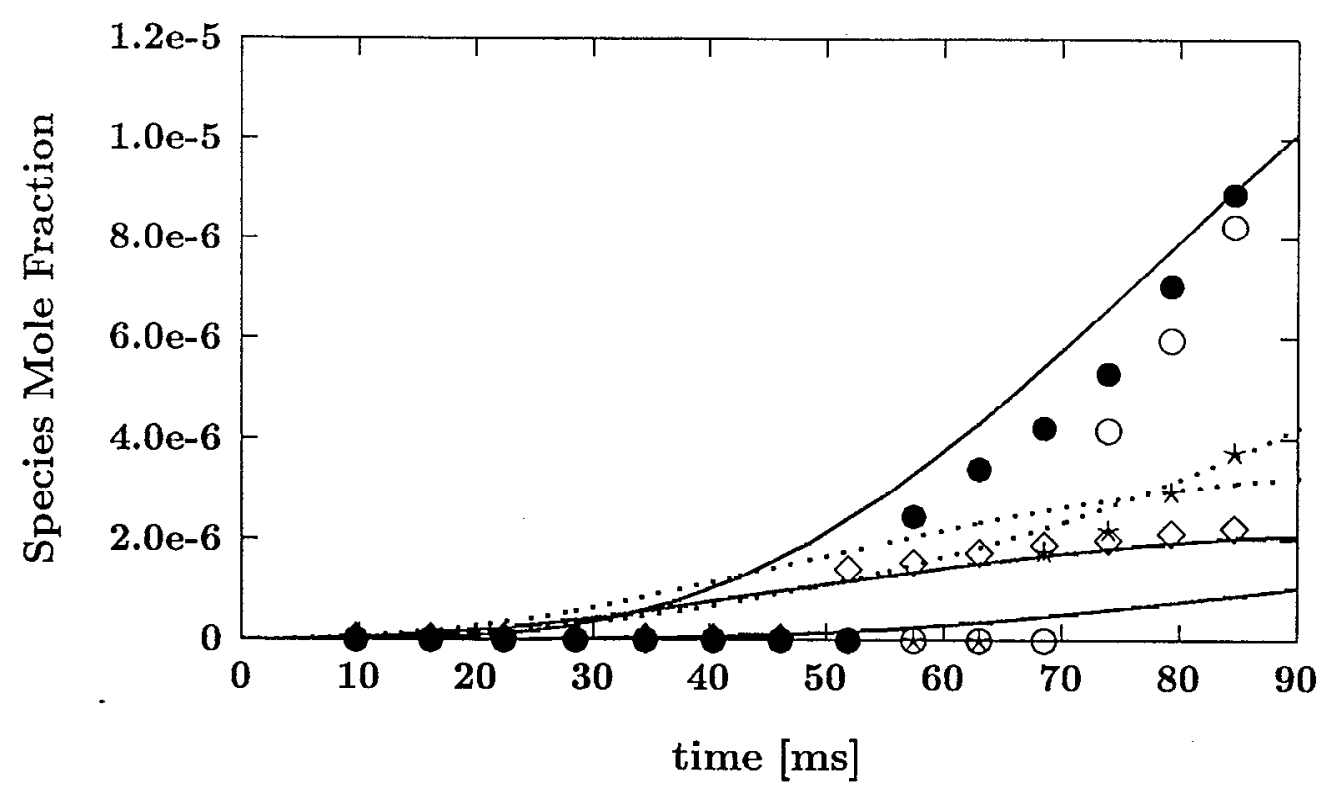

Figure 13: $0.083 \% \mathrm{iC}_{8} \mathrm{H}_{18}, \phi=0.05, \mathrm{~N}_{2}$ diluent at 6 atm and $925 \mathrm{~K}: \bullet \mathrm{C}_{3} \mathrm{H}_{4}-\mathrm{a}, \circ \mathrm{C}_{2} \mathrm{H}_{4}$, * $\mathrm{aC}_{5} \mathrm{H}_{10} \diamond \diamond \mathrm{jC}_{8} \mathrm{H}_{16},-\mathrm{iC}_{8} \mathrm{H}_{16}$ (prediction only). Dashed lines correspond to open symbols.

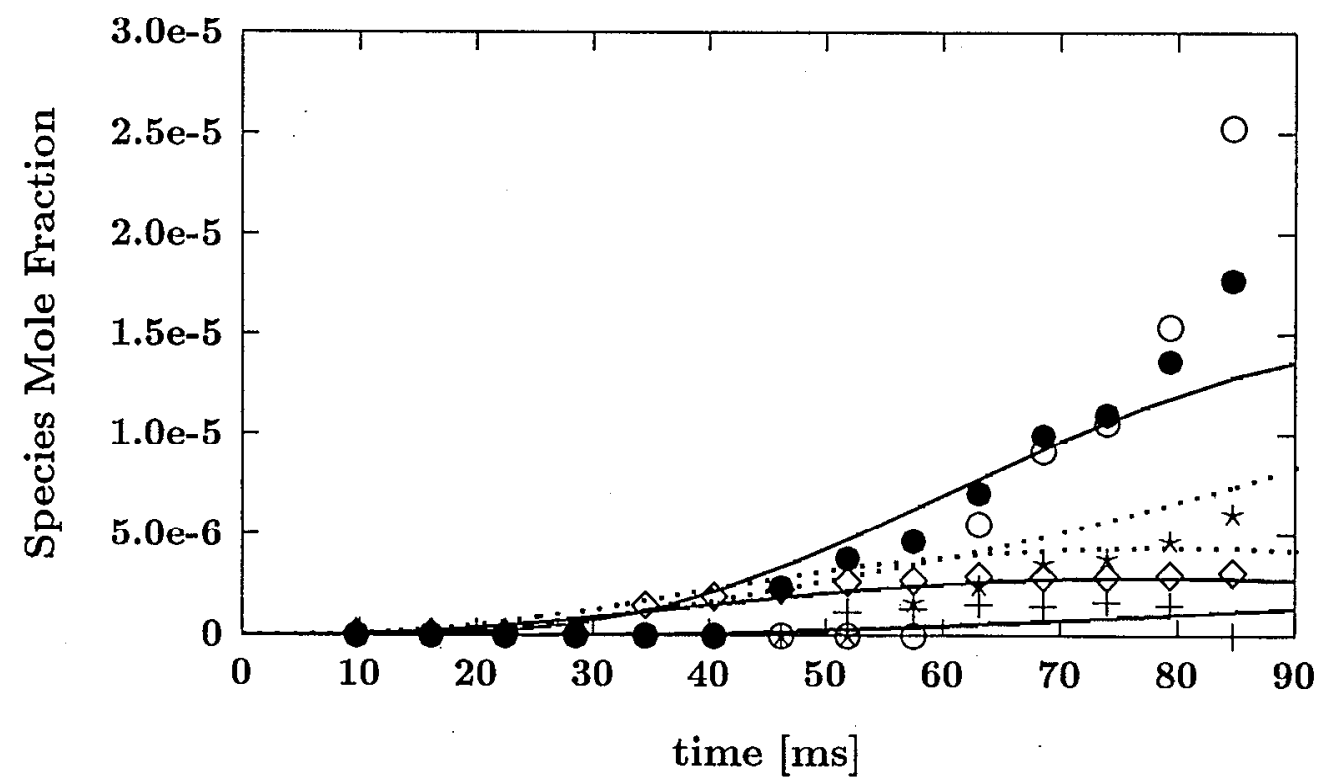

Figure 14: $0.0825 \% \mathrm{iC}_{8} \mathrm{H}_{18}, \phi=0.05, \mathrm{~N}_{2}$ diluent at 9 atm and $919 \mathrm{~K}: \bullet \mathrm{C}_{3} \mathrm{H}_{4}-\mathrm{a}, \circ \mathrm{C}_{2} \mathrm{H}_{4}$, * $\mathrm{aC}_{5} \mathrm{H}_{10}, \diamond \mathrm{jC}_{8} \mathrm{H}_{16},+\mathrm{iC}_{8} \mathrm{H}_{16}$. Dashed lines correspond to open symbols. 


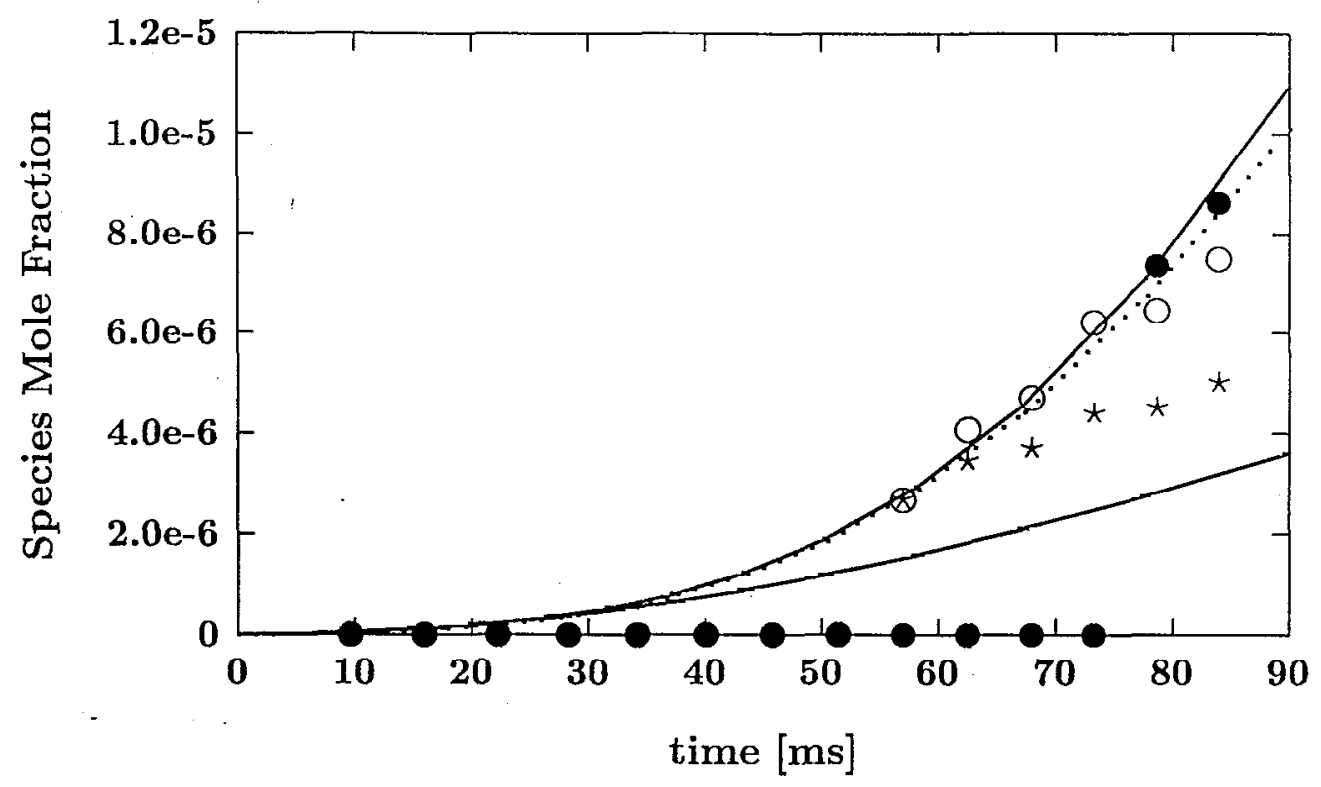

Figure 15: $0.083 \% \mathrm{iC}_{8} \mathrm{H}_{18}, \phi=0.05, \mathrm{~N}_{2}$ diluent at $3 \mathrm{~atm}$ and $930 \mathrm{~K}:-\mathrm{CH}_{3} \mathrm{COCH}_{3}$, 。 $\mathrm{iC}_{3} \mathrm{H}_{5} \mathrm{CHO}, \star \mathrm{iC}_{3} \mathrm{H}_{7} \mathrm{CHO}$. Dashed lines correspond to open symbols.

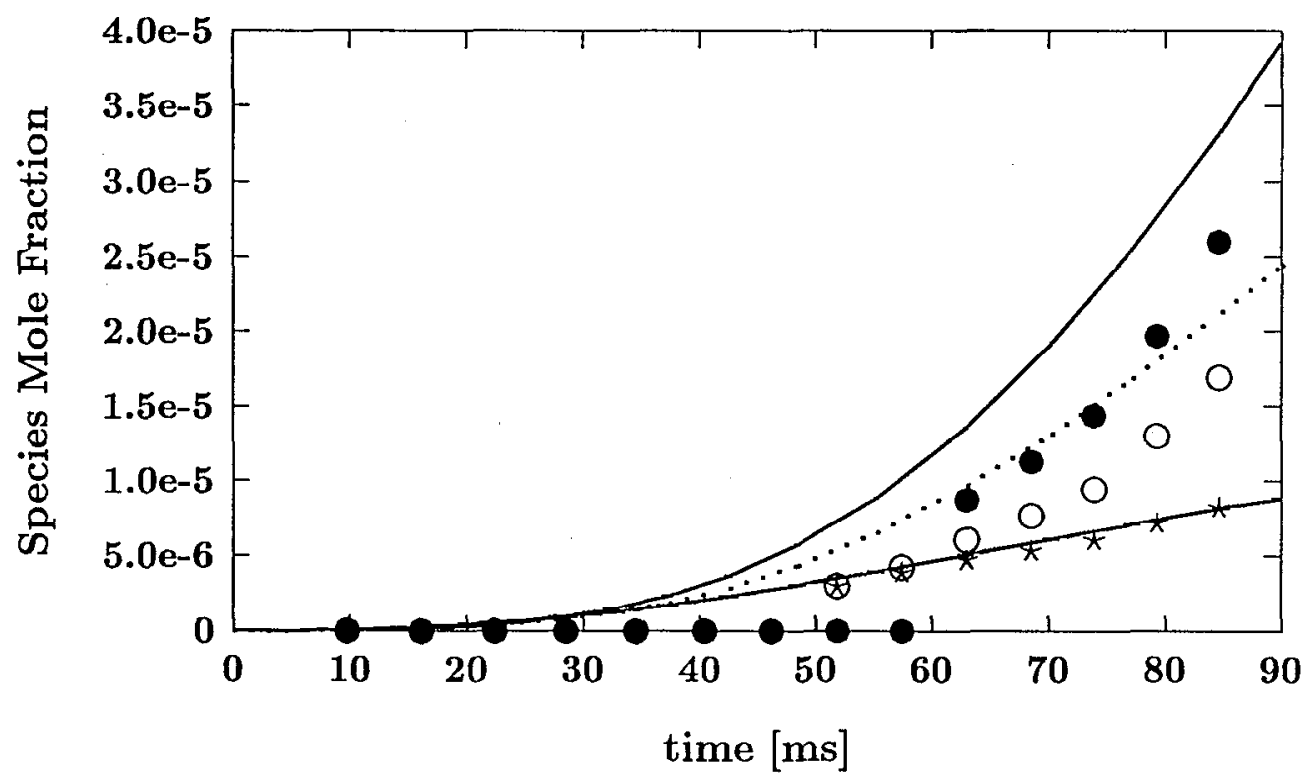

Figure 16: $0.083 \% \mathrm{iC}_{8} \mathrm{H}_{18}, \phi=0.05, \mathrm{~N}_{2}$ diluent at 6 atm and $925 \mathrm{~K}: \bullet \mathrm{CH}_{3} \mathrm{COCH}_{3}$, 。 $\mathrm{iC}_{3} \mathrm{H}_{5} \mathrm{CHO}, \star \mathrm{iC}_{3} \mathrm{H}_{7} \mathrm{CHO}$. Dashed lines correspond to open symbols. 


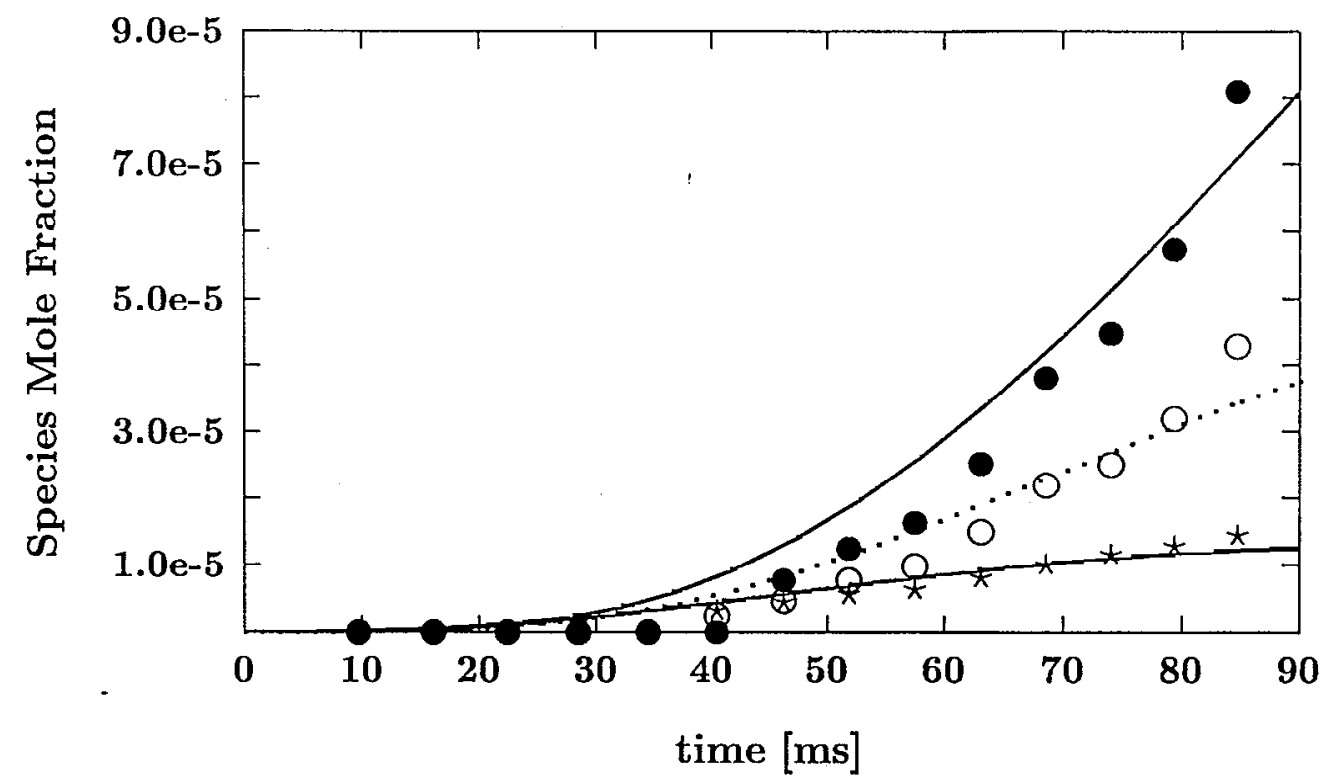

Figure 17: $0.0825 \% \mathrm{iC}_{8} \mathrm{H}_{18}, \phi=0.05, \mathrm{~N}_{2}$ diluent at 9 atm and $919 \mathrm{~K}:-\mathrm{CH}_{3} \mathrm{COCH}_{3}$, 。 $\mathrm{iC}_{3} \mathrm{H}_{5} \mathrm{CHO}, \star \mathrm{iC}_{3} \mathrm{H}_{7} \mathrm{CHO}$. Dashed lines correspond to open symbols.

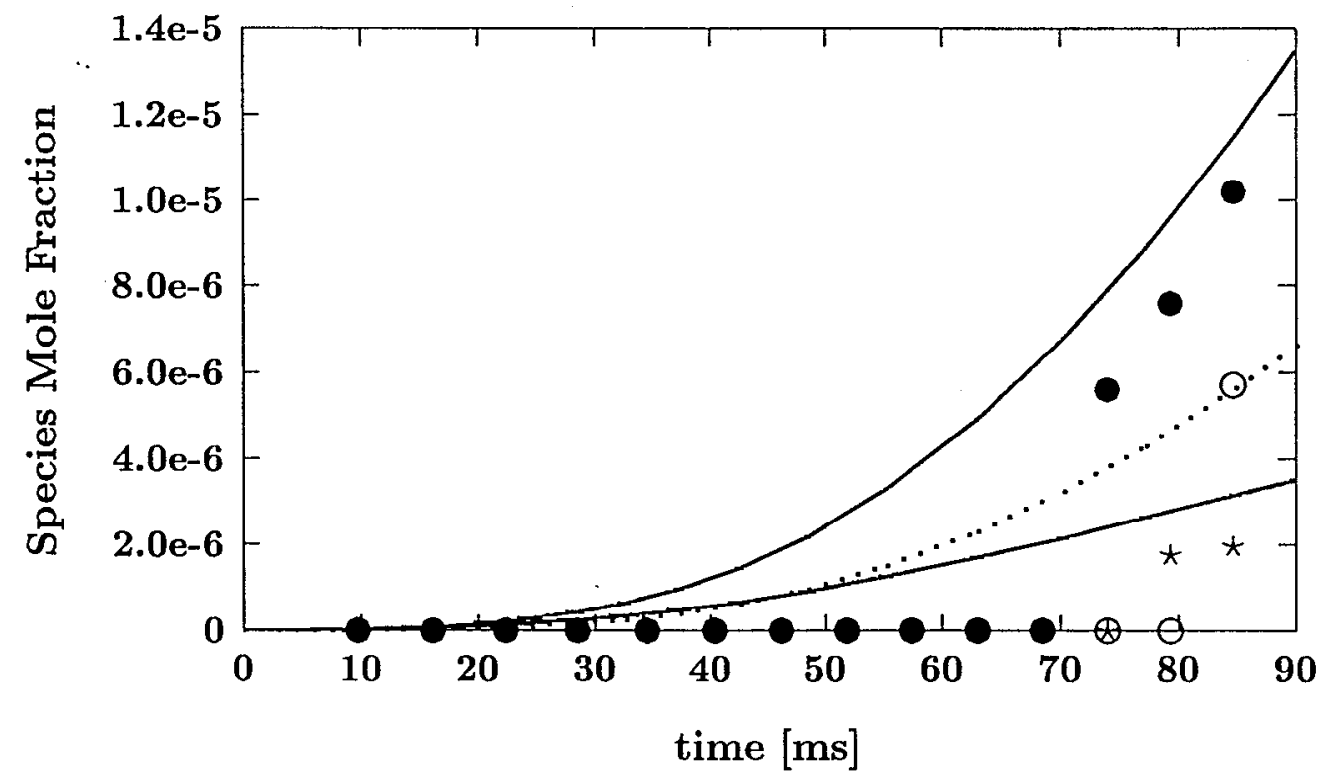

Figure 18: $0.083 \% \mathrm{iC}_{8} \mathrm{H}_{18}, \phi=0.05, \mathrm{~N}_{2}$ diluent at 6 atm and $925 \mathrm{~K}: \bullet \mathrm{CH}_{3} \mathrm{CHO}, \circ \mathrm{C}_{2} \mathrm{H}_{3} \mathrm{CHO}$, $\star \mathrm{tC}_{4} \mathrm{H}_{9} \mathrm{CHO}$. Dashed lines correspond to open symbols. 


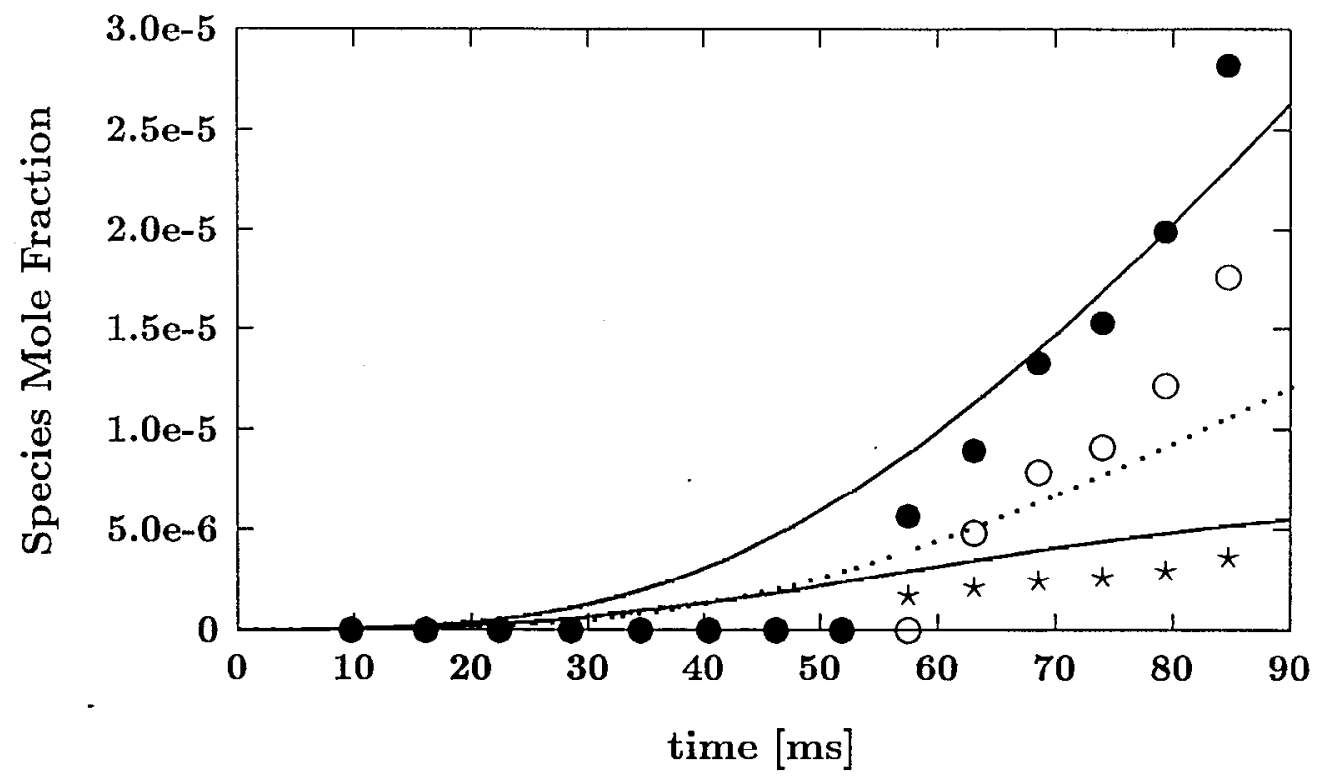

Figure 19: $0.0825 \% \mathrm{iC}_{8} \mathrm{H}_{18}, \phi=0.05, \mathrm{~N}_{2}$ diluent at 9 atm and $919 \mathrm{~K}:-\mathrm{CH}_{3} \mathrm{CHO}$, 。 $\mathrm{C}_{2} \mathrm{H}_{3} \mathrm{CHO}, \star \mathrm{tC}_{4} \mathrm{H}_{9} \mathrm{CHO}$. Dashed lines correspond to open symbols.

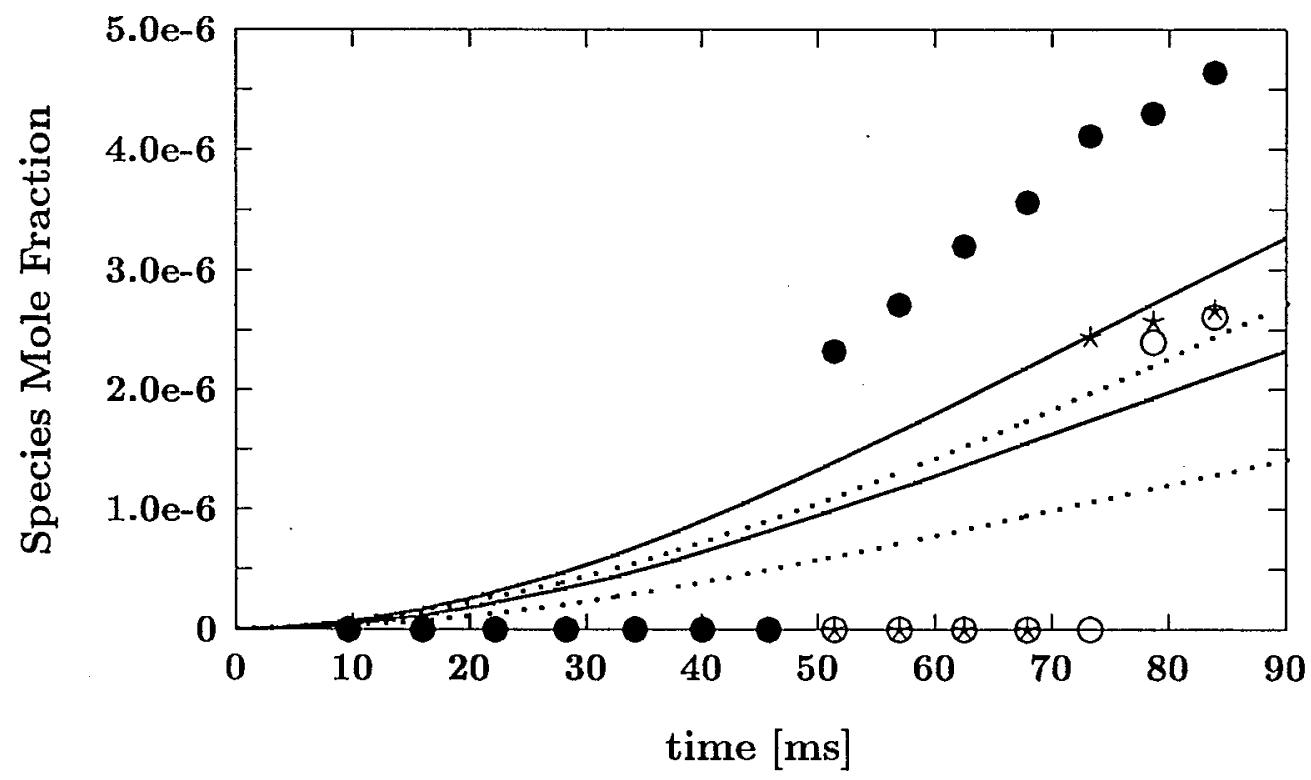

Figure 20: $0.083 \% \mathrm{iC}_{8} \mathrm{H}_{18}, \phi=0.05, \mathrm{~N}_{2}$ diluent at 3 atm and $930 \mathrm{~K}: \bullet \mathrm{iC}_{8}$ eterac, $\circ \mathrm{iC}_{4} \mathrm{H}_{8} \mathrm{O}$, $\star \mathrm{iC}_{8}$ eterab, $\cdots \mathrm{iC}_{8}$ eterbc (prediction only). Dashed lines correspond to open symbols. 


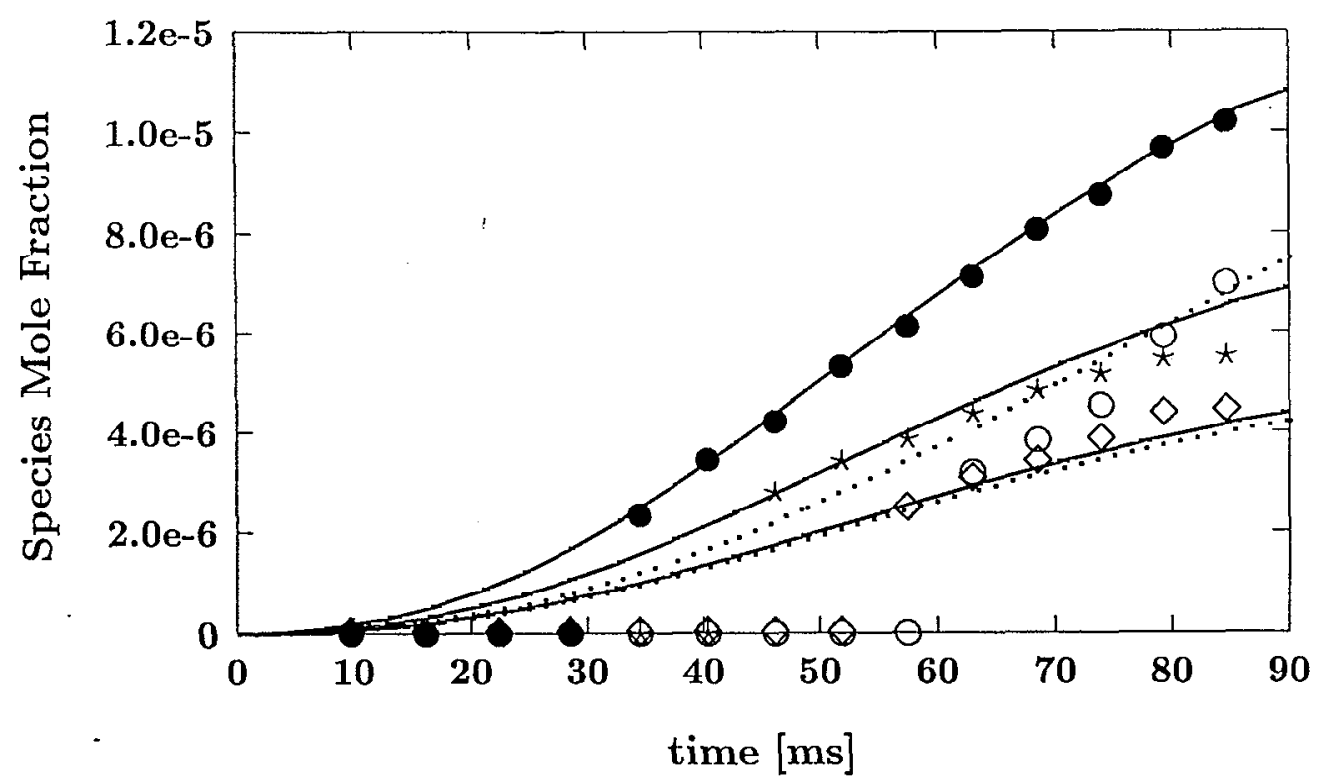

Figure 21: $0.083 \% \mathrm{iC}_{8} \mathrm{H}_{18}, \phi=0.05, \mathrm{~N}_{2}$ diluent at 6 atm and $925 \mathrm{~K}: \bullet \mathrm{iC}_{8}$ eterac, $\circ \mathrm{iC}_{4} \mathrm{H}_{8} \mathrm{O}$, $\star \mathrm{iC}_{8}$ eterab, $\diamond \mathrm{iC}_{8}$ eterbd, $-\mathrm{iC}_{8}$ eterbc (prediction only). Dashed lines correspond to open symbols.

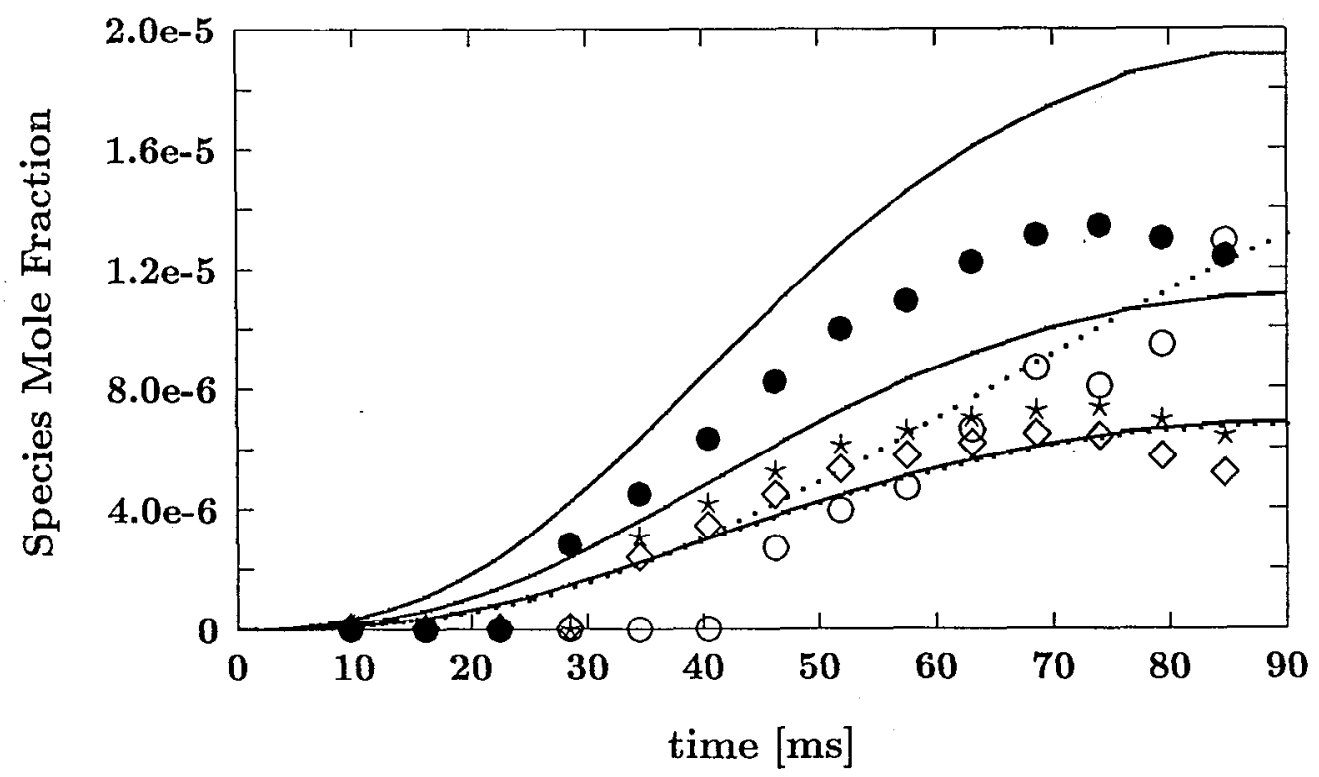

Figure 22: $0.0825 \% \mathrm{iC}_{8} \mathrm{H}_{18}, \phi=0.05, \mathrm{~N}_{2}$ diluent at 9 atm and $919 \mathrm{~K}: \bullet \mathrm{iC}_{8}$ eterac, $\circ \mathrm{iC}_{4} \mathrm{H}_{8} \mathrm{O}$, $\star \mathrm{iC}_{8}$ eterab, $\diamond \mathrm{iC}_{8}$ eterbd, $-\mathrm{iC}_{8}$ eterbc (prediction only). Dashed lines correspond to open symbols. 